\title{
Status of MWth Integrated Gasification Fuel Cell (IGFC) Power Generation System Demonstration in China
}

\section{Chang Wei}

NICE

Zhien Liu ( $\square$ zhien.liu@chnenergy.com.cn )

NICE https://orcid.org/0000-0002-2540-9123

Chufu Li

NICE

Surinder Singh

NICE America

Haoren Lu

Nexant

\section{Yudong Gong}

NICE

\section{Pingping Li}

NICE

Hanlin Wang

NICE

Xia Yang

NICE

Ming Xu

NICE

\section{Research}

Keywords: Integrated gasification fuel cell (IGFC), Solid oxide fuel cell, Stack module, Carbon dioxide capture, Oxygen combustor

Posted Date: May 31st, 2020

DOI: https://doi.org/10.21203/rs.3.rs-27942/v1

License: (c) (1) This work is licensed under a Creative Commons Attribution 4.0 International License. 



\title{
Status of $M_{\text {th }}$ Integrated Gasification Fuel Cell (IGFC) Power Generation System Demonstration in China
}

\author{
Chang Wei ${ }^{1}$, Zhien Liu ${ }^{1,{ }^{*}}$, Chufu $\mathrm{Li}^{1}$, Surinder Singh ${ }^{2}$, Haoren $\mathrm{Lu}^{3}$, Yudong Gong ${ }^{1}$, Pingping Li ${ }^{1}$, Hanlin Wang ${ }^{1}$, Xia \\ Yang ${ }^{1}$, Ming $X u^{1}$ \\ ${ }^{1}$ National Institute of Clean-and-low-Carbon Energy, Beijing, China \\ ${ }^{2}$ NICE America Research, Mountain View, US \\ ${ }^{3}$ Nexant, San Francisco, US \\ (c) The Editorial Office of Journal of Coal Science and Technology and Springer-Verlag Berlin Heidelberg 2014
}

\begin{abstract}
This paper provides status update of IGFC power generation system being developed at National Institute of Clean-and-Low-Carbon (NICE) at $\mathrm{MW}_{\text {th }}$ scale. This system is designed to use coal as fuel to produce syngas as a first step similar to integrated gasification combined cycles (IGCC). Subsequently, the solid oxide fuel cell system is used to convert chemical energy to electricity electrochemically without combustion, which is different from IGCC. This system leads to a higher efficiency as compared to a traditional coal-fired power plant. The unreacted fuel in the SOFC system is transported to an oxygen-combustor to be converted to steam and $\mathrm{CO}_{2}$. Through heat recovery system, the steam is condensed and removed, and $\mathrm{CO}_{2}$ is enriched and captured for sequestration or other application, such as co-electrolysis of $\mathrm{CO}_{2}$ and $\mathrm{H}_{2} \mathrm{O}$ using curtailed renewable energy for production of syngas. Comprehensive economic analysis for a typical IGFC system was performed and the results were compared with supercritical pulverized coal-fired (SCPC) power plant, showing the cost of electricity (COE) of IGFC could be up to $20 \%$ lower than that by SCPC with $\mathrm{CO}_{2}$ capture. The SOFC stacks selected for IGFC development were tested and qualified under both hydrogen and simulated coal syngas fuel showing good consistency and stable long term performance. Experimental results using SOFC stacks and thermodynamic analysis (using ASPEN Plus) indicate that the hydrogen to $\mathrm{CO}$ ratio of the syngas is preferred to be 1.68 or higher to avoid carbon deposition inside of the fuel pipe. For lower $\mathrm{H}_{2} / \mathrm{CO}$ ratio, steam to $\mathrm{CO}$ ratio needs to be higher. Besides, the steam needs to be mixed well with the syngas above $100^{\circ} \mathrm{C}$ and below the temperatures where carbon formation is thermodynamically favored. The $20 \mathrm{~kW}$ SOFC power generation unit is being developed with design system conditions of $20 \mathrm{~kW}$ maximum power, current density of $0.334 \mathrm{~A} / \mathrm{cm}^{2}$, DC efficiency of $50.41 \%$, and fuel utilization of $80 \%$. A $100 \mathrm{~kW}$ subsystem will consist of $6 \times 20 \mathrm{~kW}$ power generation units, and the $\mathrm{MW}_{\text {th }}$ IGFC system will consist of $5 \times 100 \mathrm{~kW}$ sub-systems.
\end{abstract}

Keywords Integrated gasification fuel cell (IGFC), Solid oxide fuel cell, Stack module, Carbon dioxide capture, Oxygen-combustor

\section{Introduction}

Due to vast coal reserve and its lower cost, coal-fired power plant provides majority of electricity need in China, which is one of the major sources of $\mathrm{CO}_{2}$ emission and air pollution. In 2019, China's $\mathrm{CO}_{2}$ emission is more than the sum of that produced by Europe and the United States. In the Paris agreement signed by international leaders in 2015, Chinese government promised $\mathrm{CO}_{2}$ emission in China will be peaked in 2035 and then gradually decreased to below 3 Gt by 2050 compared to 9 Gt in 2015 (Jiang, 2017). CHINA Energy is one of the leading energy companies in China and ranks 107 for world 500 companies. Its coal mining is up to 500 MMT per year and the total 
electricity generated by coal-fired power plant is 190 GW per year, about $45 \%$ of total electricity by CHINA Energy. The old coal-fired power plant has lower efficiency, up to $35-40 \%$ and also generates significant $\mathrm{CO}_{2}$ emission as well as other impurities, such as NOx, $\mathrm{SO}_{2}$, and dust, to cause air pollution. The supercritical pulverized coal (SCPC) power plant has better efficiency, up to $48 \%$. However, its cost is higher if $\mathrm{CO}_{2}$ is captured and stored.

Integrated Gasification Combined Cycle (IGCC) and Integrated Gasification Fuel Cell (IGFC) power generation system with $\mathrm{CO}_{2}$ capture are being developed recently to use coal effectively and reduce air pollution and $\mathrm{CO}_{2}$ emission. Compared to IGCC, the advantage of IGFC is higher efficiency and lower overall cost, especially pressurized system. IGFC is expected to be the most efficient power generation system in coal-fired power generation system (Liese et al., 2010, Ghosh et al., 2006, Braun et al., 2012). A typical IGFC power generation system includes: 1) coal gasification subsystem to convert solid coal to coal syngas and remove all kinks of impurities; 2) high temperature solid oxide fuel cell system; and 3) $\mathrm{CO}_{2}$ capture subsystem. A simple IGFC system is similar to an IGCC system, but the gas turbine (GT) power island is replaced by a fuel cell island. Since the fuel cell is a system to convert chemical energy to electricity through electrochemical reaction, higher power generation efficiency can be achieved than IGCC. $64.5 \%(\mathrm{HHV})$ and $53.6 \%$ power generation efficiency have been demonstrated using high-grade bituminous coal and low-grade coal, respectively, by National Institute of Advanced Industrial Science and Technology (AIST) in Japan (Nomura et al., 2011). Developing the IGFC power generation system to convert old coal-fired power plant to green energy form to significantly reduce $\mathrm{CO}_{2}$ emission and air pollution is an urgent task for CHINA Energy. Since July 2017, National Institute of Clean-and-Low-Carbon Energy (NICE), fully owned by CHINA Energy, has been developing an IGFC demonstration system working with key partners, such as Huaneng Clean Energy Research Institute, China University of Mining Technology Being, Huaqing Inc. etc. High quality coal syngas is being mass-produced at the Coal-to-Oil plant in Ningmei, Ningxia, one of the subsidiaries of CHINA Energy, which will be used as fuel for the IGFC system being developed by NICE. Therefore, the coal gasification and coal syngas purification processes will not be discussed in this paper. Oxygen-combustion of exhaust fuel from the fuel cell system and $\mathrm{CO}_{2}$ capture will be discussed in separate paper (Wang, 2020). The development status of the high-temperature solid oxide fuel cell (SOFC) power generation system, including the system concept design and initial experimental results are presented and discussed.

\section{Economic analysis of IGFC system}

The team first performed comprehensive economic analysis for a typical IGFC systems mentioned in the DOE NETL report (DOE/NETL, 2014) which consists of three main subsystems: 1) coal gasification and removal of variety of impurities; 2) SOFC power generation subsystem with anode loop recycle; and 3) oxygen-combustion and heat recovery system generation (HRSG) for $\mathrm{CO}_{2}$ capture, see Figure 1 adapted from DOE/NETL reports (DOE, 2014 \& 2015). An ASPEN Plus model was built to estimate costs for Case 1.1 and Case 2.1 in the DOE NETL report using $\mathrm{CoP}$ gasifier. Assumptions and parameters being used in the model are listed in table 1. Costing methods were used from various references. First, IGCC with CoP gasifier without $\mathrm{CO}_{2}$ capture (Case B4A) was used for cost estimates for most non SOFC components. Case B5A was used to evaluate the costs of the Selexol plant and adapt them for IGFC costing cases. Case12F was used for estimating cryogenic separation of $\mathrm{CO}_{2}$ from other components (DOE, 2015). The QGESS capital cost scaling methodology was used for scaling the components to the size estimated for the IGFC cases (DOE, 2013). The US estimates were converted to CNY using a conversion rate of USD:CNY of 1:6.5. Figure 2 shows a comparison of a number of cases. The SCPC and SCPC with $\mathrm{CO}_{2}$ capture estimates have been previously reported in the literature by our previous studies (Surinder, 2018). The SCPC study was used to calculate a capital cost and operating cost reduction factors between US and China. These factors were used to update the IGFC US cases to calculate the China IGFC costs. It is recognized that this is a simplified methodology for calculating IGFC costs in China. A more detailed analysis is suggested for another study where every unit operation is modeled and sized specific for China conditions. Such a work is out of scope for this study. The Base IGFC case is modeled vs Case 1.1 in the DOE study with an SOFC degradation rate of $1.5 \% / 1000 \mathrm{hrs}$. The lower degradation rate case is modeled according to Case 1.2 of DOE study with an SOFC degradation rate of $0.2 \% / 1000 \mathrm{hrs}$. The advanced IGFC case is modeled according to Case 3.1 in the DOE study at a pressure of 8 bars instead of 20 bars used in the DOE study. A capacity factor of $80 \%$ was chosen for Case 1.1, 1.2, CN 1.1 and CN 1.2 and $85 \%$ for Case 3.1 and CN 3.1 to compare with DOE NETL cases. The results are

Table 1 Assumptions for ASPEN Plus model

\begin{tabular}{|l|r|r|r|}
\hline CASE & 1.1 & 1.2 & 3.1 \\
\hline Anode Feed CH4 content (mol\%) & $5.8 \%$ & $5.8 \%$ & $10.9 \%$ \\
\hline SOFC Operating Pressure (bar) & 1 & 2 & 8 \\
\hline SOFC Degradation Rate (\%/1000h) & 1.5 & 0.2 & 0.2 \\
\hline SOFC Overpotential (mV) & 140 & 141 & 70 \\
\hline Capacity Factor & 80 & 80 & 85 \\
\hline SOFC Stack Cost (CNY/kW) & 1463 & 1463 & 1463 \\
\hline Inverter Efficency, $\%$ & 97 & 97 & 97 \\
\hline
\end{tabular}


shown in Figure 2. Comparing different cases it is clear that China based systems are consistently lower in cost vs. US. It is also clear that IGFC costs are higher as compared to SCPC without and with $\mathrm{CO}_{2}$ capture at an SOFC degradation rate of $1.5 \% / 1000 \mathrm{hrs}$. The IGFC system can become competitive compared to
SCPC with $\mathrm{CO}_{2}$ capture if SOFC degradation rate can be reduced to $0.2 \% / 1000 \mathrm{hrs}$. Such SOFC technology has been demonstrated at $250 \mathrm{~kW}$ level in both US and Japan (Kobayashi, 2015). IGFC system at higher pressure indicates reduction in COE further.

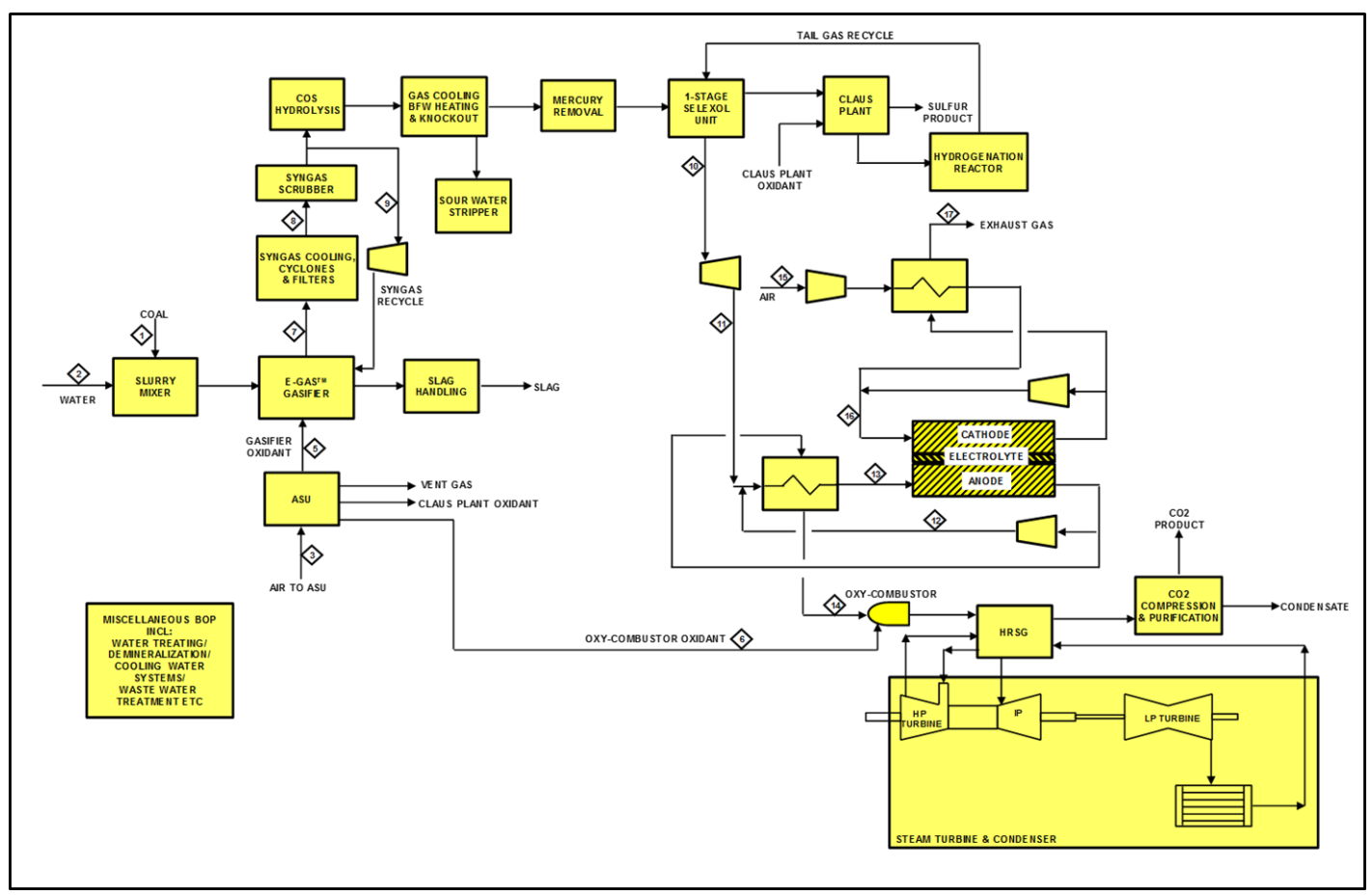

Figure 1 A typical IGFC system for economic analysis (from DOE/NETL report, 2014)

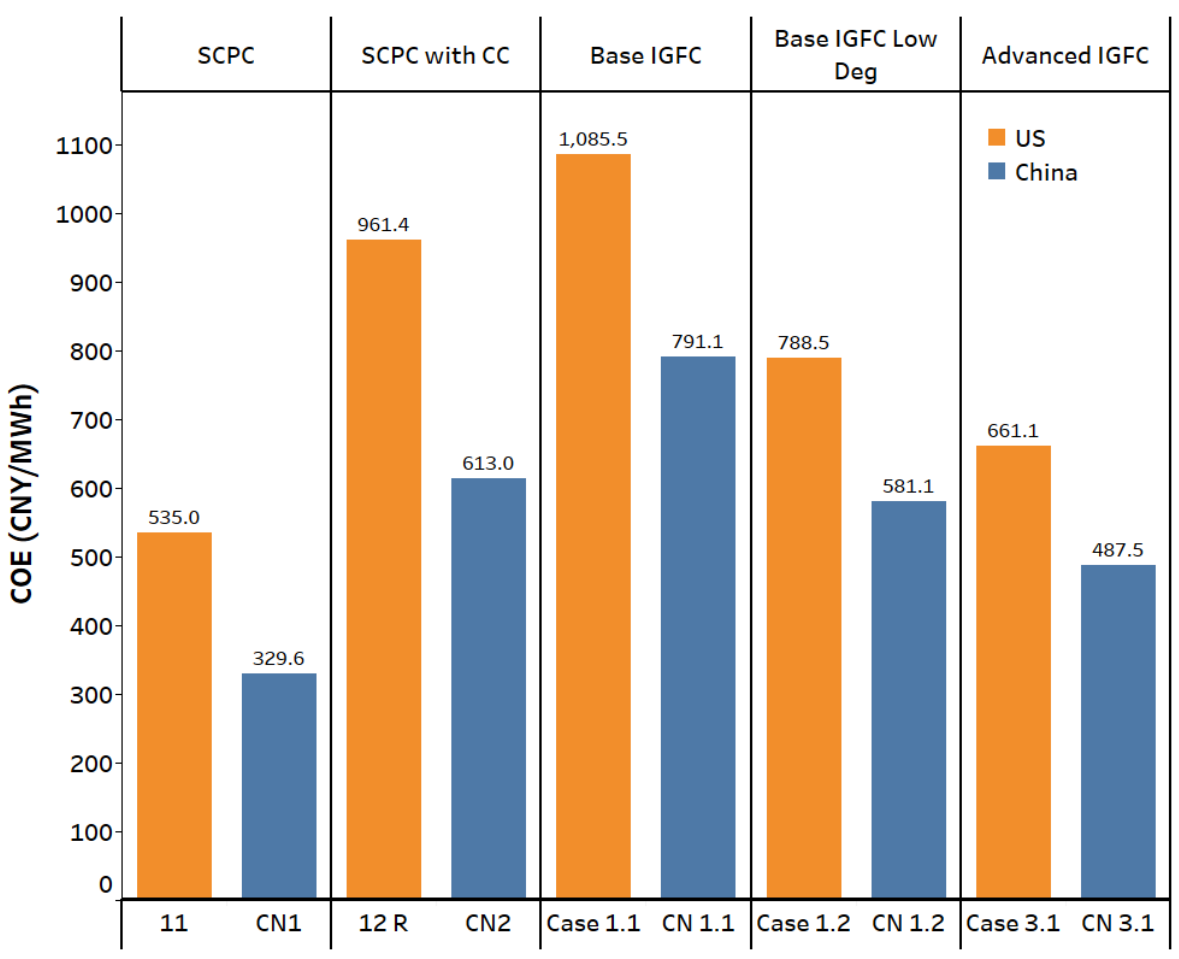

Figure 2: Cost of electricity (COE) of various IGFC systems cases as compared to SCPC without and with CO2 capture for US and China. 


\section{IGFC system development}

\subsection{SOFC stack selection and evaluation}

Since CHINA Energy is a traditional energy company focusing on mainly coal mining, coal-fired power plant, wind power, hydropower, and solar power recent years, SOFC technology is not available in house. The team communicated many domestic and international SOFC developers intending to get high quality and low cost stack for this program. Based on the considerations, such as quality, availability, cost as well as mass production capability and quality control, the stacks from Elcogen in Finland, Sanhuan in Chaozhou, China, Huaqing in Suzhou, China, and China University of Mining and Technology at Beijing were considered for evaluation. Stack leakage was inspected for all incoming stacks and followed by electrochemical testing using hydrogen fuel between $700-800^{\circ} \mathrm{C}$ in ambient pressure based on stack specification provided by suppliers. More testing data from Sanhuan stacks were generated due to its availability. Figure 3 summarized testing results (stack voltage and power output vs. current density) of three individual stacks. For stack 1 , the stack power output is $981 \mathrm{~W}$ at current density of $250 \mathrm{~mA} / \mathrm{cm}^{2}$, and increased to $1021 \mathrm{~W}$ at current density of $270 \mathrm{~mA} / \mathrm{cm}^{2}$. When current density is higher than $270 \mathrm{~mA} / \mathrm{cm}^{2}$, the stack voltage formed a tail, off the trend line. To better understand the effect of testing conditions on stack performance, the stack was tested under different fuel flow rate and all tests were performed at $750^{\circ} \mathrm{C}$ (stack 2 and 3 in Figure 3). It can be seen that when the flow rate was increased from 9 SLPM (standard liter per minute) for stack 1 to 12 SLM for stack 2, and 13 SLPM for stack 3, the stack voltage shows good linearity.

The testing data of stack 1 was further analyzed to better understand the stack properties, such as area specific resistance (ASR, ohm- $\mathrm{cm}^{2}$ ), and stack performance, such as fuel utilization and DC efficiency under different testing conditions. Figure 4 summarized average stack ASR, fuel utilization and $D C$ efficiency vs. current density at average temperature of $750^{\circ} \mathrm{C}$ with fixed fuel (9 SLPM) and air flow (25 SLPM) rate. It can be seen that, at current density of $250 \mathrm{~mA} / \mathrm{cm}^{2}$, the stack average ASR, fuel utilization, and DC power efficiency are $0.308 \mathrm{ohm}-\mathrm{cm}^{2}$, $82.7 \%$, and $58.9 \%$, respectively. With increasing current density from $250 \mathrm{~mA} / \mathrm{cm}^{2}$ to $270 \mathrm{~mA} / \mathrm{cm}^{2}$, the stack average ASR, fuel utilization and DC efficiency are increased to $0.330 \mathrm{ohm}-\mathrm{cm}^{2}, 90.7 \%$, and $63.1 \%$, respectively. Above $270 \mathrm{~mA} / \mathrm{cm}^{2}$, stack average ASR increased significantly. and a tail was formed from voltage vs. current density curve (Figure 3). Most likely fuel starvation happened at local area within the stack, especially near the stack outlet, when current density is higher than $270 \mathrm{~mA} / \mathrm{cm}^{2}$ with fuel flow rate of 9 SLPM. Based on the data analysis, it seems to be safe to operate Sanhuan stack at current density of around $250 \mathrm{~mA}$, or fuel utilization of about $80 \%$. The slightly stack ASR change with current density (below 270 $\mathrm{mA} / \mathrm{cm}^{2}$ ) may attribute to the cell or stack open circuit voltage (OCV) change under different fuel compositions. With increasing current density of the stack, hydrogen will decrease and steam will increase quickly in the fuel stream with electrochemical reaction, which will change stack OCV. It seems average stack ASR has correlation with the fuel composition which resulted in the gradual change with increasing stack current density.

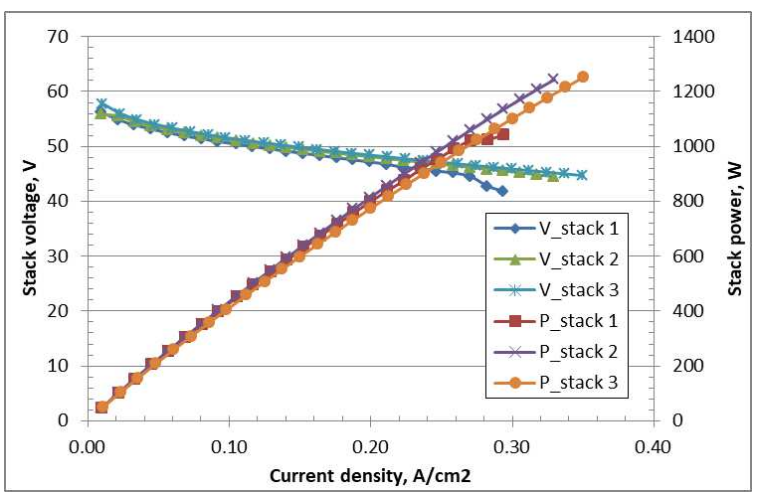

Figure $3 \mathrm{~V}$-I curves of SOFC stack (fuel flow rate is 9.0S LPM for stack 1, 12.0 SLPM for stack 2, and 13 SLPM for stack 3)

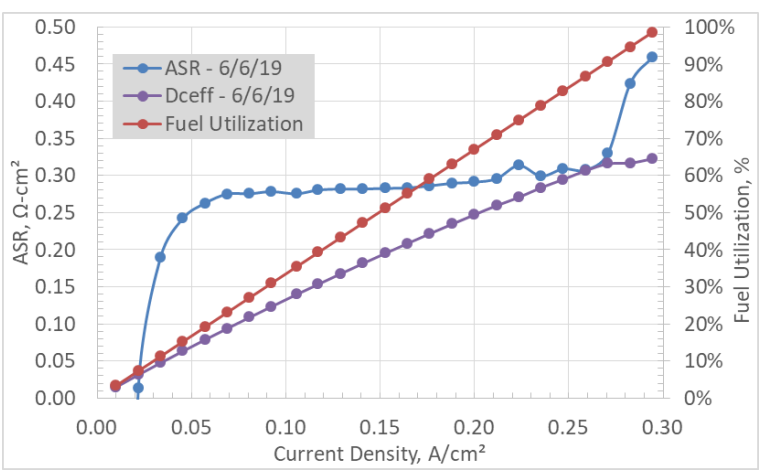

Figure 4 SOFC stack average ASR, DC power efficiency and fuel utilization vs. current density

Short term stack durability was also tested up to 540 hours under different conditions. In period one, the fuel and air flows are 13 SLPM and 36 SLPM, 
respectively, and then the fuel flow decreased to 10.6 SLPM while keeping constant air flow in period 2. Within both periods, noticeable stack degradation is observed. In period 3, air flow was increased to 69 SLPM while keeping fuel flow no change. In period 4 , the stack current was decreased from 24 A to $22 \mathrm{~A}$, and back to $24 \mathrm{~A}$ for period 5 . It can be seen that there is no noticeable stack degradation for periods 3 to 5 even though the duration is not long enough.

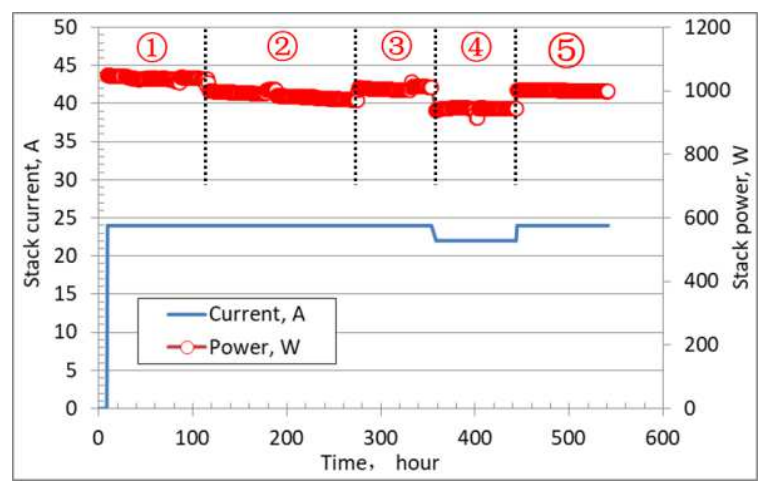

Figure 5 SOFC stack short term durability at $750^{\circ} \mathrm{C}$

\subsection{Design system operation conditions}

IGFC system being developed will be operated under coal syngas rather than hydrogen fuel. Therefore the stack performance under coal syngas needs to be evaluated and the design system operation conditions need to be defined. The coal syngas composition available for IGFC system operation is roughly $61.8 \% \mathrm{H}_{2}, 36.7 \% \mathrm{CO}$, and $1.1 \% \mathrm{~N}_{2}$ with minor content of $\mathrm{CO}_{2}$ and $\mathrm{CH}_{4}$. Based on thermodynamics, $\mathrm{CO}$ intends to form carbon under certain conditions, so called reverse Boudouard reaction, see equation (1), which is exothermal reaction and is thermodynamically favored at temperatures below $500^{\circ} \mathrm{C}$ based on thermodynamic analysis (Figure 6). The formed carbon could be deposited on the inner surface of fuel pipe to block fuel flow channel or enter into the stack with fuel gas stream and be deposited on anode surface. The stack performance would be affected under either case. Besides, the contact material and the material surface

$\mathrm{CO}(\mathrm{g}) \rightarrow \mathrm{C}(\mathrm{s})+\mathrm{CO}_{2}(\mathrm{~g})$

properties may also affect carbon formation. The amount of carbon formation at different temperatures was analyzed using ASPEN Plus for the syngas with different $\mathrm{H}_{2} / \mathrm{CO}$ ratio in the syngas (Figure $6 \mathrm{a}-\mathrm{c}$ ). When $\mathrm{H}_{2} / \mathrm{CO}$ ratio is $1.68(61.8 \% \mathrm{H}, 37.7 \% \mathrm{CO})$, the high end temperature for carbon formation was decreased from about $400^{\circ} \mathrm{C}$ to $300^{\circ} \mathrm{C}$ with increasing steam/CO ratio from 1 to 1.15 . When $\mathrm{H}_{2} / \mathrm{CO}$ ratio is 2.3
$(69.7 \% 2, \quad 30.3 \% \mathrm{CO})$, the high end temperature for

$\mathrm{H} 2 / \mathrm{CO}$ ratio 1.68:1

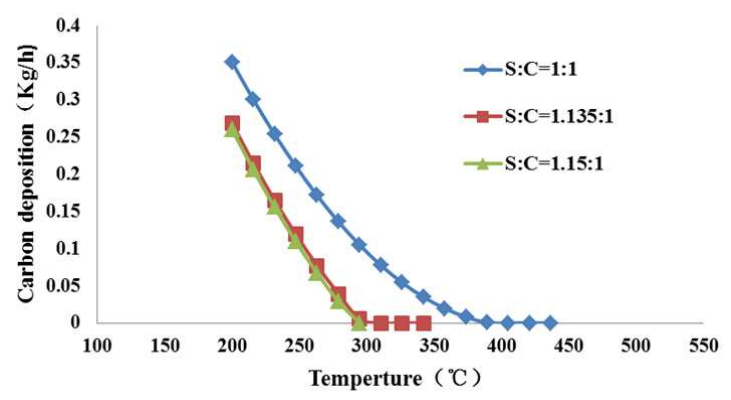

(a) $\mathrm{H} 2 / \mathrm{CO}=1.68: 1(61.8 \% \mathrm{H}, 37.7 \% \mathrm{CO})$

H2/CO ratio 2.3:1

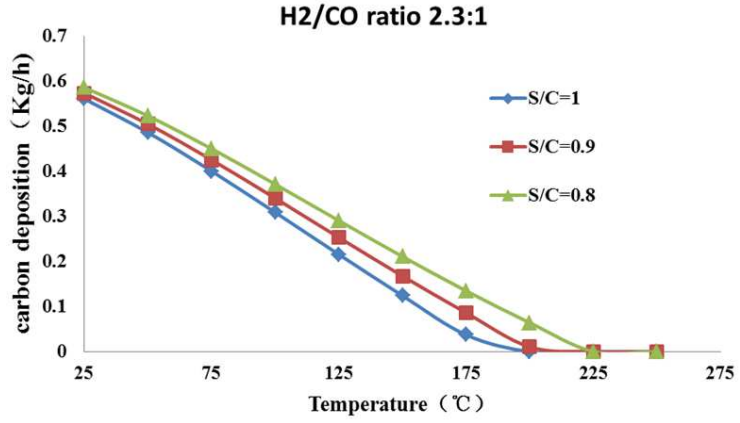

(b) $\mathrm{H} 2 / \mathrm{CO}=2.3: 1\left(69.7 \% \mathrm{H}_{2}, 30.3 \% \mathrm{CO}\right)$

H2/CO ratio 2.9:1

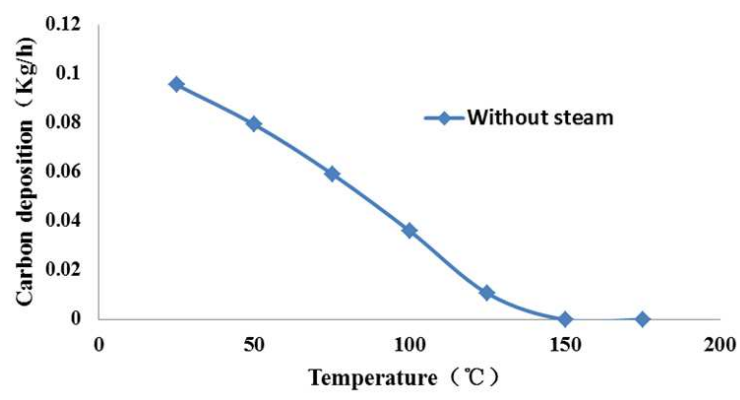

(c) $\mathrm{H} 2 / \mathrm{CO}=2.9: 1(74.4 \% \mathrm{H}, 25.6 \% \mathrm{CO})$

Figure 6 Potential carbon deposition analysis within fuel pipe for coal syngas with different $\mathrm{H} / \mathrm{CO}$ ratio using ASPEN Plus

carbon formation changed to about $200^{\circ} \mathrm{C}$ and the steam/CO ratio, when changing from 0.8 to 1.0 , shows no significant effect on this temperature which is determined by the thermodynamics of the reaction. Above this temperature, the Gibbs free energy change of reaction (1), $\Delta \mathrm{Ge}$, is positive and the reaction would not happen. If further increasing $\mathrm{H}_{2} / \mathrm{CO}$ ratio to 2.9 $\left(74.4 \% \mathrm{H}_{2}, 25.6 \% \mathrm{CO}\right)$, the highest temperature for carbon formation is decreased to about $150^{\circ} \mathrm{C}$ even without steam addition. From kinetics point of view, the reaction speed is too slow at lower temperatures and the reaction (1) may not happen since the fuel gas 
stream will pass this temperature range with high speed, 14 SLPM, under system operation conditions.

Stack test was also performed to better understand its performance and behavior under coal syngas (Figure 7). To make sure this specific stack has the same performance as others under hydrogen, the

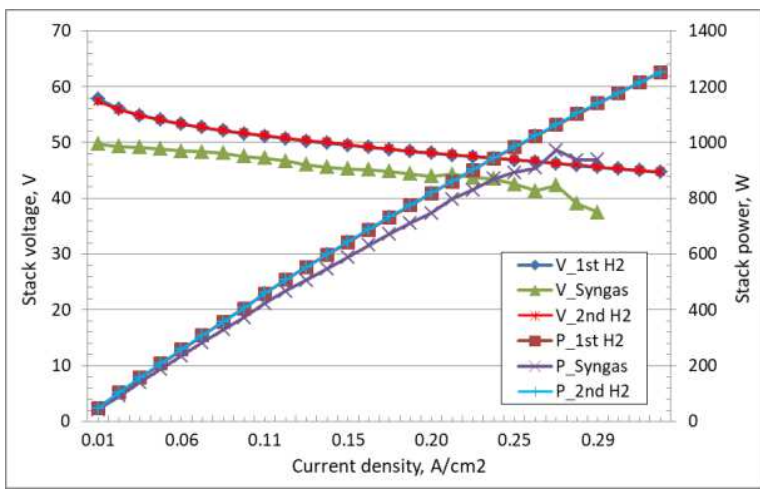

Figure 7 SOFC stack performance under H2 (flow rate: $13 \mathrm{SLM})$ and simulated coal syngas $\left(61.8 \% \mathrm{H}_{2}\right.$, $37.7 \% \mathrm{CO}$, flow rate:13 SLM with steam/CO ratio of 1.1)

stack was first tested under hydrogen with flow rate of 13 SLPM at $750^{\circ} \mathrm{C}$. The $\mathrm{V} / \mathrm{j}$ curve $\left(\mathrm{V}_{-} 1^{\text {st }} \mathrm{H}_{2}\right)$ shows good linearity and the stack generated $1252 \mathrm{~W}\left(\mathrm{P}_{-} 1^{\text {st }}\right.$ $\mathrm{H}_{2}$ ) at the current density of $330 \mathrm{~mA} / \mathrm{cm}^{2}$ indicating a good stack. Then the fuel was switched to simulated coal syngas with composition of $61.8 \% \mathrm{H}_{2}$ and $37.7 \% \mathrm{CO}$ (steam/CO ratio is 1 ). The OCV change is as expected due to $\mathrm{pO}_{2}$ change in fuel stream, and the $\mathrm{V} / \mathrm{j}$ curve is linear up to the current density of 270 $\mathrm{mA} / \mathrm{cm}^{2}$. Above that, both voltage and power curve tailed down from the trend line of the original plot. The test was shut-down for inspection. Significant carbon deposition inside of fuel inlet pipe was identified. The stack was reheated to $750^{\circ} \mathrm{C}$ under safe gas $\left(5 \% \mathrm{H}_{2}\right.$ balanced with nitrogen), and then being purged with hydrogen at $750^{\circ} \mathrm{C}$ and tested again after OCV is stabilized. The $\mathrm{V} / \mathrm{j}$ curve of the second test under hydrogen (V_2 $\left.{ }^{\text {nd }} H 2\right)$ generally overlapped with the $\mathrm{V} / \mathrm{j}$ curve of the first hydrogen test indicating the carbon damage to stack performance is temporary which is recoverable when fuel steam is switched from simulated syngas to hydrogen. The analysis of the test set-up after testing indicates that the steam was added into the fuel stream near the entrance of the furnace where the temperature may possibly be well above the temperature range of carbon formation. That means the carbon has been formed when the steam was added into the fuel inlet pipe.

Second stack test was performed at $725^{\circ} \mathrm{C}$ (stack average temperature) using simulated coal syngas $\left(61.8 \% \mathrm{H}_{2}, 37.7 \% \mathrm{CO}\right.$, steam/CO ratio: $\left.\sim 0.7\right)$ as fuel to make sure the steam is added into the fuel stream at lower temperature before carbon has been formed. The stack performance was stable during testing and series of tests were successfully completed at current densities between 258.2 and $282.9 \mathrm{~mA} / \mathrm{cm}^{2}$ with high voltage per cell (table 2). 1022W stack power and $53.2 \%$ DC efficiency were achieved. Fuel utilization is up to $84.6 \%$ with no sign of fuel starvation. However, carbon was still observed inside of fuel inlet system during after-test inspection. This is possibly due to the lower steam/CO ratio or insufficient mixing between fuel gas and steam.

Table 2 SOFC stack testing results with syngas

\begin{tabular}{|c|c|c|c|c|c|}
\hline Test No & $\begin{array}{c}\text { Current } \\
\text { density, } \\
\mathrm{mA} / \mathrm{cm} 2\end{array}$ & $\begin{array}{c}\text { Voltage/Cell, } \\
\text { V }\end{array}$ & $\begin{array}{c}\text { Stack power, } \\
\text { W }\end{array}$ & Uf, \% & DC eff, \% \\
\hline 1 & 258.2 & 0.845 & 943.9 & 80.7 & 51.2 \\
\hline 2 & 282.9 & 0.835 & 1022.4 & 82.8 & 51.9 \\
\hline 3 & 280.6 & 0.837 & 1016.3 & 84.6 & 53.2 \\
\hline
\end{tabular}

1) Fuel utilization, stack power and DC efficiency were controled by slightly adjusting fuel flow rate and current density

2) stack average temperature: $725^{\circ} \mathrm{C}$

3) Steam/CO ratio: $\sim 0.7$

4-stack module was tested, after successful single stack testing, using pipeline coal syngas at Coal-to-Oil plant in Ningmei, Ningxia province. During test, the coal syngas was mixed with partial hydrogen to get a composition with higher $\mathrm{H}_{2} / \mathrm{CO}$ ratio of $2.8\left(72.9 \% \mathrm{H}_{2}\right.$, $26.0 \% \mathrm{CO}$, steam/CO ratio is 1$)$. Module power, fuel utilization, and DC power efficiency are $1.4 \mathrm{~kW} /$ stack, $84.5 \%$, and $53 \%$, respectively. The module was operated under coal syngas and hydrogen mixture for up to about 350 hours without noticeable degradation trend. Furthermore, the post-test analysis shows no carbon deposition in fuel pipeline. Detailed experimental results will be published separately (Xu, 2020)

Based on thermodynamic analysis and stack performance verification test, the coal syngas composition from $\mathrm{H}_{2} / \mathrm{CO}$ ratio form 1.68 to 2.8 could be used as fuel for IGFC power generation system. If the syngas has lower $\mathrm{H}_{2} / \mathrm{CO}$ ratio, more steam is required to mix with the coal syngas above $100^{\circ} \mathrm{C}$ and below the temperatures where the carbon formation is thermodynamically favored inside of fuel inlet pipeline surface to prevent carbon deposition, which may affect system performance if steam content is too high. If the coal syngas has higher $\mathrm{H}_{2} / \mathrm{CO}$ ratio, carbon deposition can be prevented with less steam or even no steam in fuel stream. More stack performance data with different coal syngas composition and operation conditions are needed to achieve highest power generation using available coal syngas or managing to 
get coal syngas composition which may benefit IGFC system power generation and efficiency.

\subsection{0kW SOFC power generation unit development}

IGFC system flow chart is shown in Figure 8, in which pipeline coal syngas is used. Sulfur is removed before syngas enters into SOFC stacks. After electrochemical reaction in the stack, outlet fuel, which still contains about $10-20 \%$ flammable, is fed into oxygen-combustor to convert $\mathrm{H}_{2}$ into steam and $\mathrm{CO}$ into $\mathrm{CO}_{2}$. After going through heat recovery system, steam is condensed and was removed as water, and $\mathrm{CO}_{2}$ is enriched to higher than $95 \%$ for capture. Based on this flow chart, 20kW SOFC power generation unit has been developing since April 2019 using performance data of single stack and 4-stack module obtained under both hydrogen and simulated or real coal syngas as fuel. The system process flow chart is shown in Figure 9. The fuel system consists of a mixing tank to thoroughly mix coal syngas and steam at temperatures above $100^{\circ} \mathrm{C}$ to prevent carbon formation in fuel inlet before entering into the stack, and a heat exchanger to heat the fuel stream to desired temperature, which is $\sim 700^{\circ} \mathrm{C}$ for the stack selected for our IGFC system. The fuel flow is single pass without recycle and the design fuel utilization is $80 \%$. The exhaust fuel, after cooling and separating the water from the gas stream, will be fed into an oxygen-combustor to burn the residual fuel and enrich $\mathrm{CO}_{2}$ equal or higher than $95 \%$ for $\mathrm{CO}_{2}$ capture, which can be stored or utilized, such as producing $\mathrm{H}_{2}-\mathrm{CO}$ syngas through co-electrolysis of carbon dioxide and steam. The detailed experimental results will be published separately (Hanlin, 2020). The stack module includes 4 stack towers and each tower was built from 4 stacks, which is able to generate maximum $20 \mathrm{~kW}$ power under current density of $336 \mathrm{~mA} / \mathrm{cm}^{2}$ and $171.2 \mathrm{~V} /$ stack tower, respectively.

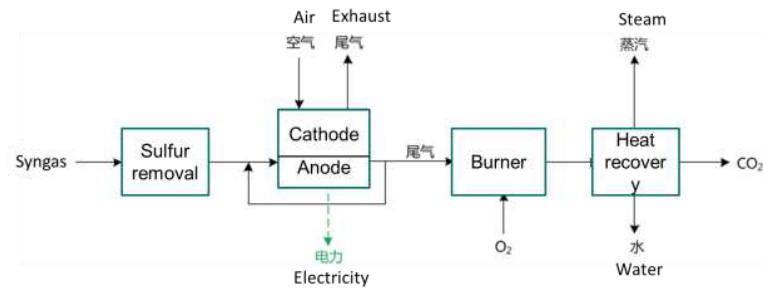

Figure 8 IGFC system flow chart using pipeline coal syngas

During long term steady state operation, the module was designed to operate at $0.25 \mathrm{~A} / \mathrm{cm}^{2}$ and the power output is $15 \mathrm{~kW}$ (see table 3 ). CFD simulation was conducted to better understand the fuel and air flow within the stack module since it's important for heat management and keeping the healthy stack during operation. The simulation results are promising (Figure 10). The air flow is pretty uniform and the fuel flow variation is within $\pm 5 \%$, which is acceptable for the system operation under design conditions. Uniform

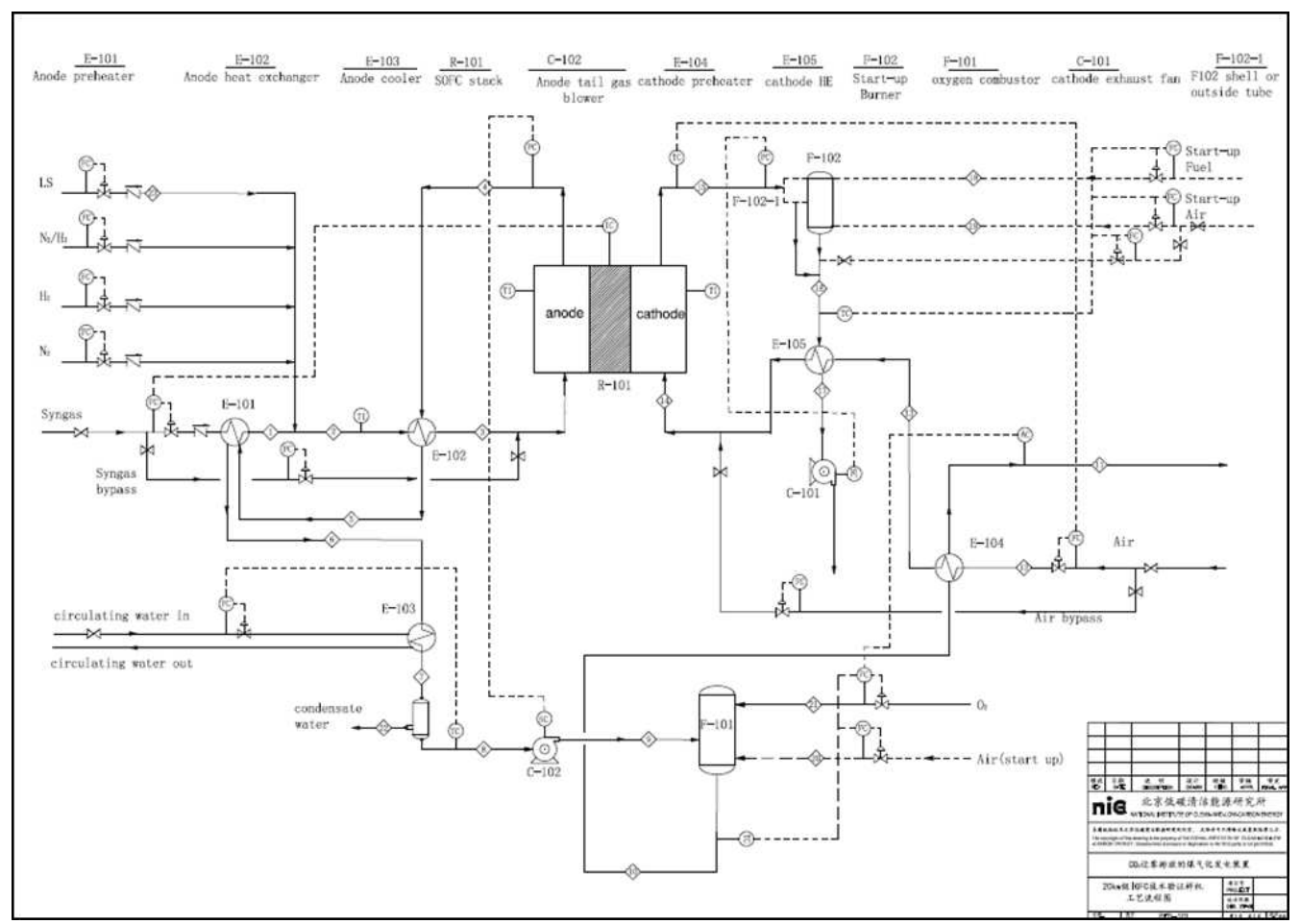

Figure 9 Process flow chart of the $20 \mathrm{~kW}$ SOFC system 
fuel flow will ensure that there will have no fuel starvation in any local area within the stack during system operation. The uniform air flow could ensure that the temperature difference of all stacks in the module can be controlled within specification. That is, the air inlet temperature of each stack is $700^{\circ} \mathrm{C}$ and outlet temperature is $5800^{\circ} \mathrm{C}$ to maintain best performance and healthy stack. The cathode loop consists of a gas start-up burner, and the hot exhaust

Table 3 Design operation conditions of $20 \mathrm{~kW}$ power generation system,

\begin{tabular}{|c|c|c|c|}
\hline & unit & $\begin{array}{c}\text { Design } \\
\text { conditions }\end{array}$ & $\begin{array}{c}\text { Maximum } \\
\text { power output }\end{array}$ \\
\hline Design power output & $\mathrm{KW}$ & 14.9 & 20 \\
\hline Coal syngas flow rate & $\mathrm{Kg} / \mathrm{h}$ & 4.89 & 6.569 \\
\hline Air flow rate & $\mathrm{Kg} / \mathrm{h}$ & 188.13 & 290 \\
\hline Current density & $\mathrm{A} / \mathrm{cm} 2$ & 0.250 & 0.336 \\
\hline Stack tower & $\mathrm{V}$ & 175.6 & 171.2 \\
\hline Design DC efficiency & $\%$ & 51.73 & 50.41 \\
\hline Fuel utilization & $\%$ & 80.00 & 80 \\
\hline Heat loss & $\mathrm{KW}$ & 2 & 2 \\
\hline
\end{tabular}

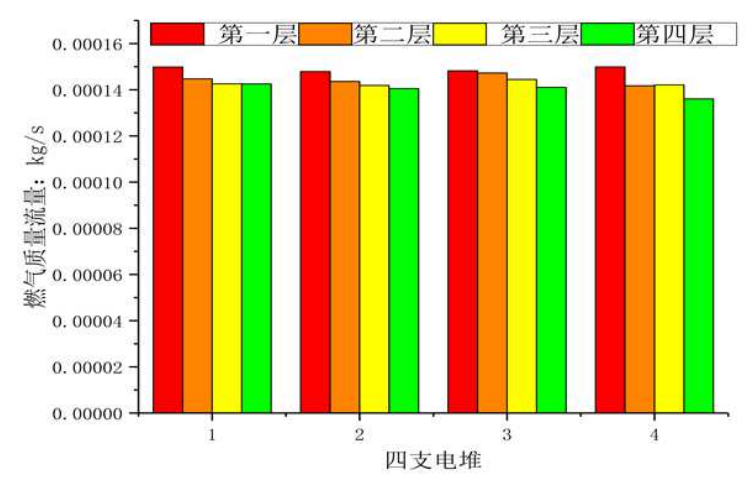

(a) Fuel flow distribution in SOFC stacks within $20 \mathrm{~kW}$ module

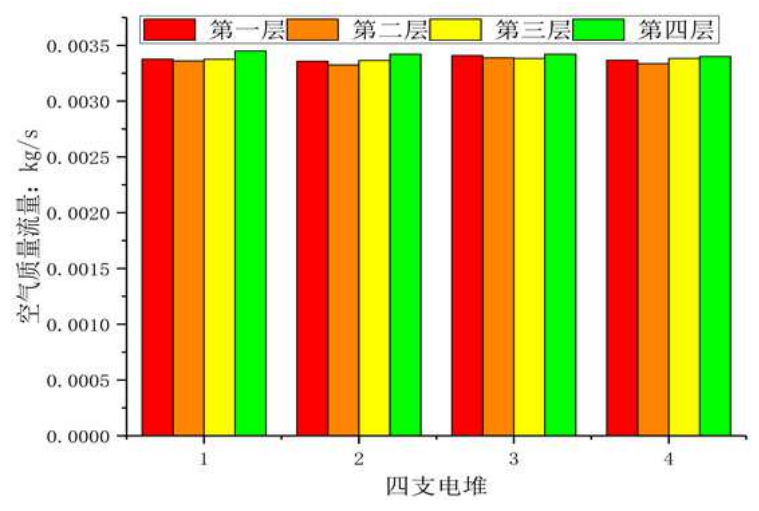

(b) Air flow distribution in SOFC stacks of $20 \mathrm{~kW}$ module

Figure 10 Gas flow distribution in SOFC stacks of $20 \mathrm{~kW}$ module

gas can be used to heat up cold air when the system starts at room temperatures. During system steady operation, the inlet air is heated up through a heat exchanger. Figure 11 shows the assembly sketch of the $20 \mathrm{~kW}$ SOFC power generation system excluding the oxygen-combustor. On the back of the sketch, it's a hot box where the SOFC module is located. The hotbox is designed to keep the fuel cell module at constant temperature during steady state operation through the selection of insulation material to keep minimize heat loss and the control of cathode gas flow rate. The front part includes fuel, air, and safe gas

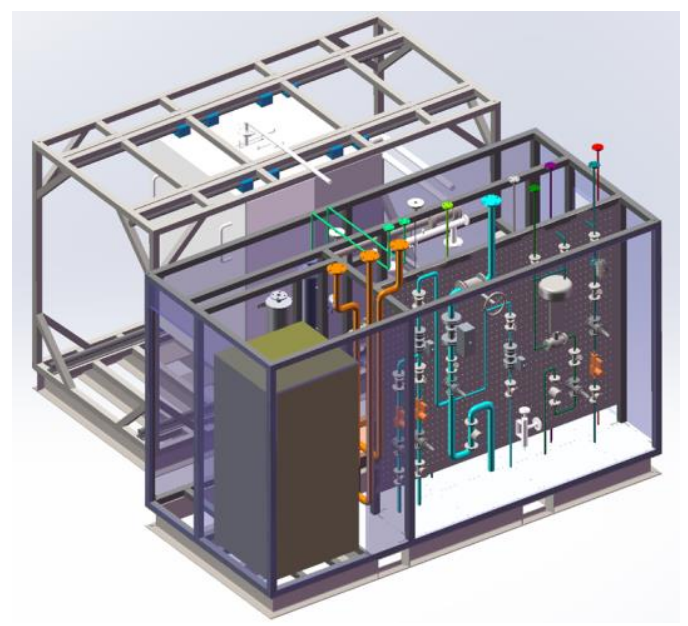

Figure 11 20kW SOFC power generation system being developed and constructed

(protect SOFC module during emergency shutdown) pipe line, control valves, flow meters, pressure meters etc., inlet fuel and air preheaters, exhaust fuel and air blowers. There is no external reformer and the majority of $\mathrm{CO}$ in the fuel gas stream expects to be converted to $\mathrm{CO}_{2}$ within fuel cell stack. This reaction is exothermal and the released heat may help self-sustainable operation of the system. However, the temperature difference between cathode inlet and outlet will be monitored closely to make sure the outlet temperature is not exceeding $800^{\circ} \mathrm{C}$.

\subsection{MWth IGFC system concept design}

The conceptual design of the $500 \mathrm{~kW}$ IGFC power generation system is shown in Figure 12. The system consists of $5 \times 100 \mathrm{~kW}$ subsystems which can be controlled separately and generated DC power is converted to AC power. There are 5-6 SOFC modules within each subsystem which are electrically connected in parallel. If any module goes wrong or need maintenance, other modules will not be affected and can continue to generate power. Within each module, there are multiple stack towers. These stack towers are electrically connected in parallel. In each stack tower, individual stack is electrically connected in 
series. The beauty of this design is that any damage, repair, or maintenance of individual stack tower, module, or subsystem will not affect the operation of other stack tower, module, or subsystem. Based on table 3 , the design voltage of the stack tower during steady state operation is $172.2 \mathrm{~V}$. This voltage may be too low for direct $\mathrm{DC} / \mathrm{AC}$ conversion, which may need to be boosted to higher DC voltage before being converted to AC power. The desired DC voltage depends on the technology of advanced DC/AC converter. The small amount of power loss through each DC booster and AC converter will be considered during system design.

The layout sketch of $100 \mathrm{~kW}$ SOFC power generation system is shown in Figure 13, which consists of $6 \times 20 \mathrm{~kW}$ fuel cell modules, and each module can generate $15 \mathrm{~kW}$ DC power during steady state operation. All SOFC modules, including the hotbox, are located on one side of the layout and control system is located on another side. Gas pipe lines, heat exchangers, fuel and air preheaters, blowers etc. are in between them. The footprint of this $100 \mathrm{~kW}$ SOFC system is roughly $7 \mathrm{~m} \times 30 \mathrm{~m}$.

Based on the conceptual design and selected SOFC stacks, materials and key components of the balance of plant (BOP), the initial cost model of the $100 \mathrm{~kW}$ fuel cell system was established, shown in Figure 14. In which the stack cost is $30.4 \%$ which is generally in the ballpark for stack cost percentage in a SOFC power generation system published by other fuel cell developers. However, the stack cost may be slightly higher in our system since we purchased the stacks from supplier and the labor cost for system assembly was counted in other cost rather than materials cost only. The heat exchanger is $7.9 \%$ and hotbox is $14.8 \%$ which expects to be reduced significantly since it was customized design and built

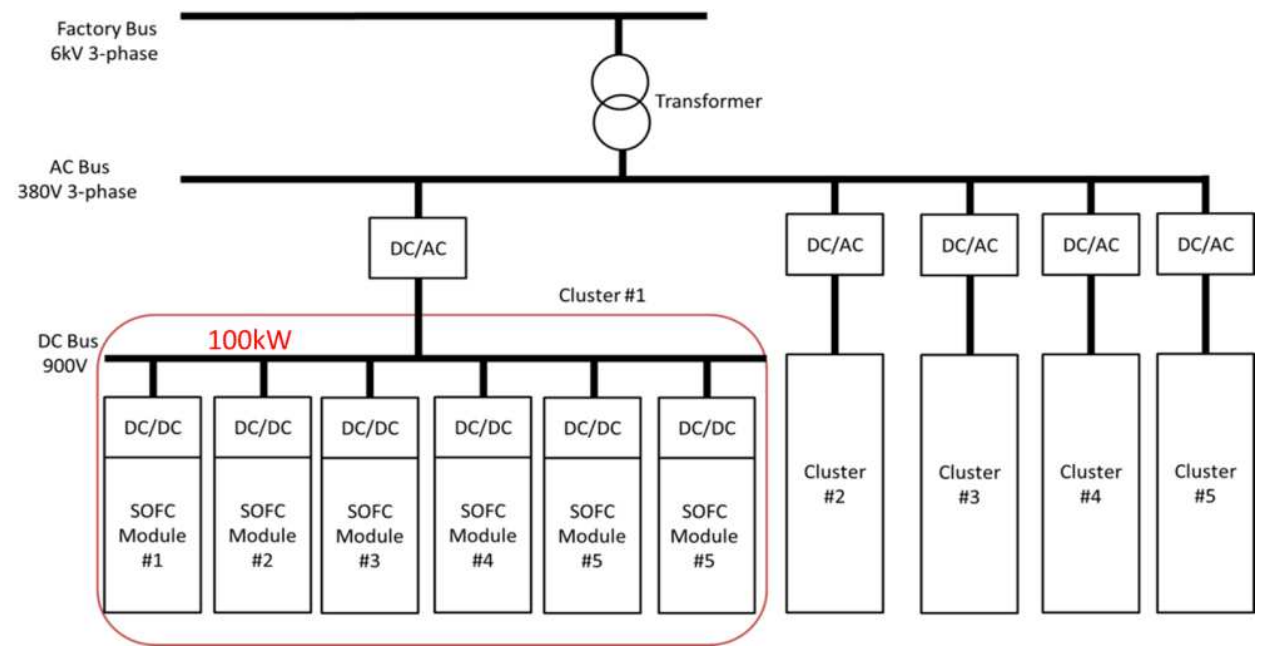

Figure $12500 \mathrm{~kW}$ SOFC power generation system conceptual design which consists of $5 \times 100 \mathrm{~kW}$ subsystem, and each subsystem consists of 5-6 SOFC modules which are electrically connected in parallel.

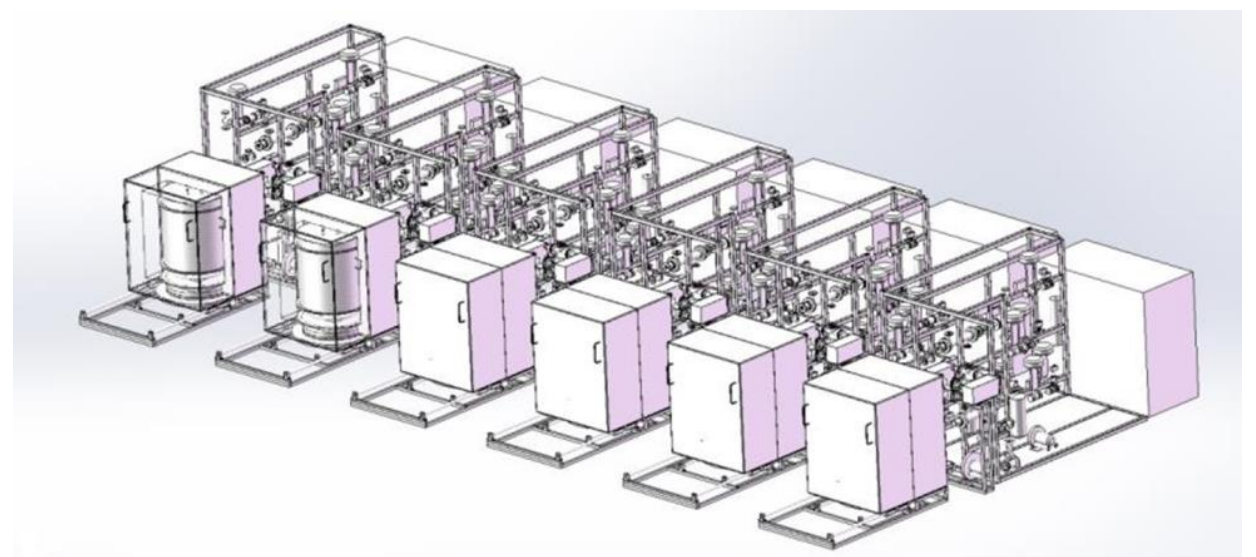

Figure $13100 \mathrm{~kW}$ SOFC power generation system conceptual design (consisting of $6 \times 20 \mathrm{~kW}$ modules for steady state operation) 
with very small quantities. With mass production, it will become standard product and the cost will be much lower. The major cost seems to be BOP related, such as gas pipe materials, gas flow and pressure control meters, fuel and air preheaters or burner during system start-up, heat exchangers during system steady state operation, blowers to transport exhaust fuel to oxygen-combustor to burn residual fuel to $\mathrm{CO}_{2}$ and steam for $\mathrm{CO}_{2}$ enrichment, and the labor cost for system assembly. Since it's a demonstration unit, the overall cost is higher. For commercial product, the system cost, including both materials and labor, can be reduced significantly.

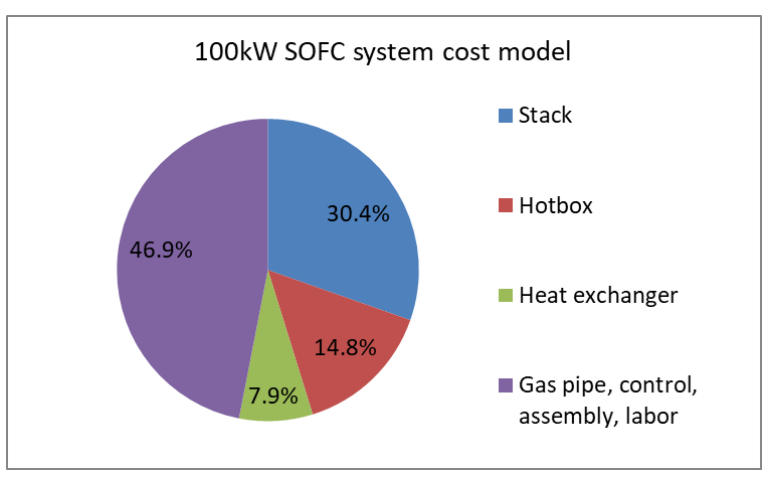

Figure 14 Cost model of 100kW SOFC system

\section{Summary}

(1) The economic analysis indicates that the advanced IGFC system (power degradation rate is $0.2 \% / 1000$ hrs or lower) with $\mathrm{CO}_{2}$ capture is competitive compared to SCPC, and its COE can be up to $20 \%$ lower than that of SCPC. The captured $\mathrm{CO}_{2}$ can be stored or co-electrolysis with $\mathrm{H}_{2} \mathrm{O}$ to produce syngas again to achieve fuel $\rightarrow$ electricity $\rightarrow$ waste $\rightarrow$ fuel cycle.

(2) Based on testing results, the SOFC stacks selected in this study shows good performance, consistency, and long term stability. Average stack ASR is $0.315 \mathrm{ohm}-\mathrm{cm}^{2}$ in hydrogen and 0.402 ohm- $\mathrm{cm}^{2}$ in simulated coal syngas. Under preferred testing conditions, stack shows no noticeable degradation during more than 500 hours of long term durability test in both hydrogen fuel and coal syngas indicating long service life. When using syngas as fuel, $\mathrm{H}_{2} / \mathrm{CO}$ and steam/CO ratio need to be well controlled to avoid carbon deposition inside of fuel pipe. $\mathrm{H}_{2} / \mathrm{CO}$ ratio of 1.68 to 2.8 and steam/CO ratio of 1 are acceptable. When $\mathrm{H}_{2} / \mathrm{CO}$ ratio is at the lower end, the mixing of steam with syngas is critical.

(3) $20 \mathrm{~kW}$ SOFC power generation unit is being developed to verify technology feasibility, which consists of four stack towers and each stack tower consists of $4 \times 1-1.5 \mathrm{~kW}$ stacks, the power output of which depends on the fuel type and operation conditions. The maximum power output of the unit is $20 \mathrm{~kW}$ when using syngas as fuel. The CFD simulation of $20 \mathrm{~kW}$ module indicates that fuel flow is uniform among 16 stacks. Flow variation is less than $\pm 5 \%$. The $100 \mathrm{~kW}$ sub-system can be built by duplicating 5-6 $\mathrm{x}$ $20 \mathrm{~kW}$ power generation units, and the MW $\mathrm{MW}_{\text {th }}$ IGFC demonstration system (total input energy is MW and output power is $500 \mathrm{~kW}$ ) will consist of $5 \times 100 \mathrm{~kW}$ sub-systems.

(4) The design operation conditions of the $20 \mathrm{~kW}$ power generation unit, 100kW sub-system, and the $\mathrm{MW}_{\text {th }}$ IGFC demonstration system are current density of $250 \mathrm{~mA} / \mathrm{cm}^{2}$ (14.9kW power output for steady state operation) and $336 \mathrm{~mA} / \mathrm{cm}^{2}$ (maximum 20kW power output), respectively, fuel utilization of $80 \%$, DC power efficiency of higher than $50 \%$, stack inlet and outlet temperatures of $700^{\circ} \mathrm{C}$ and $800^{\circ} \mathrm{C}$, respectively, DC voltage output from SOFC stack tower of higher than $171 \mathrm{~V}$. DC/DC booster may be required before DC/AC conversion.

\section{Acknowledgment}

The authors would like to thank Ministry of Science and Technology of the People's Republic of China for financial support under contract of 2017YEB061900. The authors also want to thank China Energy and Shenhua New Energy Co., Ltd. for providing cost share and Ningxia Coal Industry Co., Ltd. for their support on establishing the electrochemical testing center and providing field test site for $\mathrm{MW}_{\text {th }}$ IGFC system. The discussion with Dr. Anthony Ku is helpful for putting together the section of economic analysis of the IGFC system.

\section{References}

Jiang X, Green C, 2017. China's future emission reduction challenge and implications for global climate policy.//Journal of Climate Policy. 18, 889-901

Liese E, 2010. Comparison of preanode and postanode carbon dioxide separation for IGFC systems. //ASME J. Engineering for Gas Turbines and Power. 132, 061703-1-061703-8.

Ghosh S, De S, Energy analysis of a cogeneration plant using coal gasification and solid oxide fuel cell. //Energy 31, 345-363.

Braun R J, Kameswaran S, Yamanis J, Sun E, 2012. Highly efficient IGFC hybrid power systems employing bottoming organic rankine cycles with optional carbon capture.//Journal of Engineering for Gas Turbines and Power 134, 
021801-1-021801-15

Nomura R, Ikl N, Kurata O, Kawabata M, Tsutsumi A, Koda E, 2011. System analysis of IGFC with energy recuperation utilizing low-grade coal. // Proceedings of ASME Turbo Expo GT2011, 1-9.

DOE, 2014. Techno-Economic Analysis of Integrated Gasification Fuel Cell Systems Created by Energy Sector Planning and Analysis for SEAP \& OPPB// DOE/NETL- 341/112613, November 24, 2014

DOE/NETL, 2015. Cost and Performance Baseline for Fossil Energy Plants, Volume 1b: Bituminous Coal (IGCC) to Electricity// DOE/NETL-2015/1727, July 31, 2015, Revision 2b - Year Dollar Update

DOE/NETL, 2015. Cost and Performance Baseline for Fossil Energy Plants Volume 1b: Bituminous Coal (IGCC) to Electricity// DOE/NETL-2015/1727, July 31, 2015, Revision 2b - Year Dollar Update

DOE/NETL, 2013. Capital Cost Scaling Methodology Quality Guidelines for Energy System Studies DOE/NETL-341/013113

Surinder Singh et. al., 2018. China baseline coal-fired power plant with post-combustion $\mathrm{CO} 2$ capture: 2 . Techno-economics//International Journal of Greenhouse Gas Control 78 (2018) 429-436.

National Energy Technology Laboratory (NETL), 2013. Capital cost scaling methodology - Quality guidelines for energy systems studies.//DOE/NETL-341/013113

National Energy Technology Laboratory (NETL), 2009. Integrated gasification fuel cell performance and cost assessment.//DOE/NETL-2009/1361

Yoshinori Kobayashi, Kazuo Tomida, Masanori Nishiura, Kenichi Hiwatashi, Hiroshi Kishizawa, Koichi Takenobu, 2015. Development of next-generation large -scale SOFC toward realization of a hydrogen society.//Mitzubishi Heavy Industries Technical Review 52, 111-116

Xu M, Wang H L, Li P P, Zhang Z H, Li C F, 2020. Performance test and verification of SOFC stack module with coal syngas feeding

Wang H L, Xue Y P, Yu S E, Li P P, Li C F, 2020. Study on the combustion of exhaust fuel from the SOFC system fed with coal syngas in pure oxygen for CO2 capture//Journal of Coal Science and Technology, 
Figures

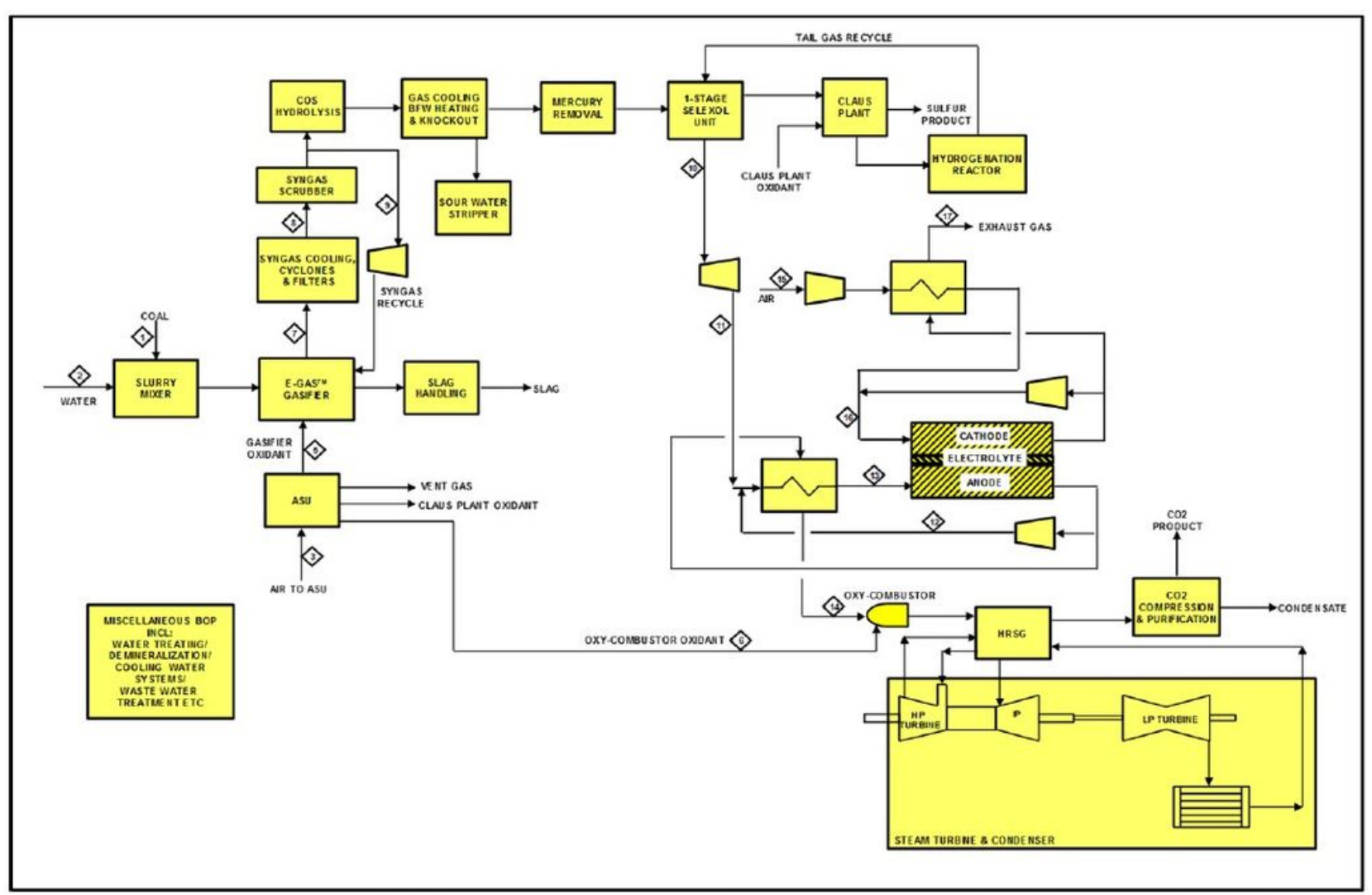

Figure 1 A typical IGFC system for economic analysis (from DOE/NETL report, 2014)

\section{Figure 1}

A typical IGFC system for economic analysis (from DOE/NETL report, 2014) 


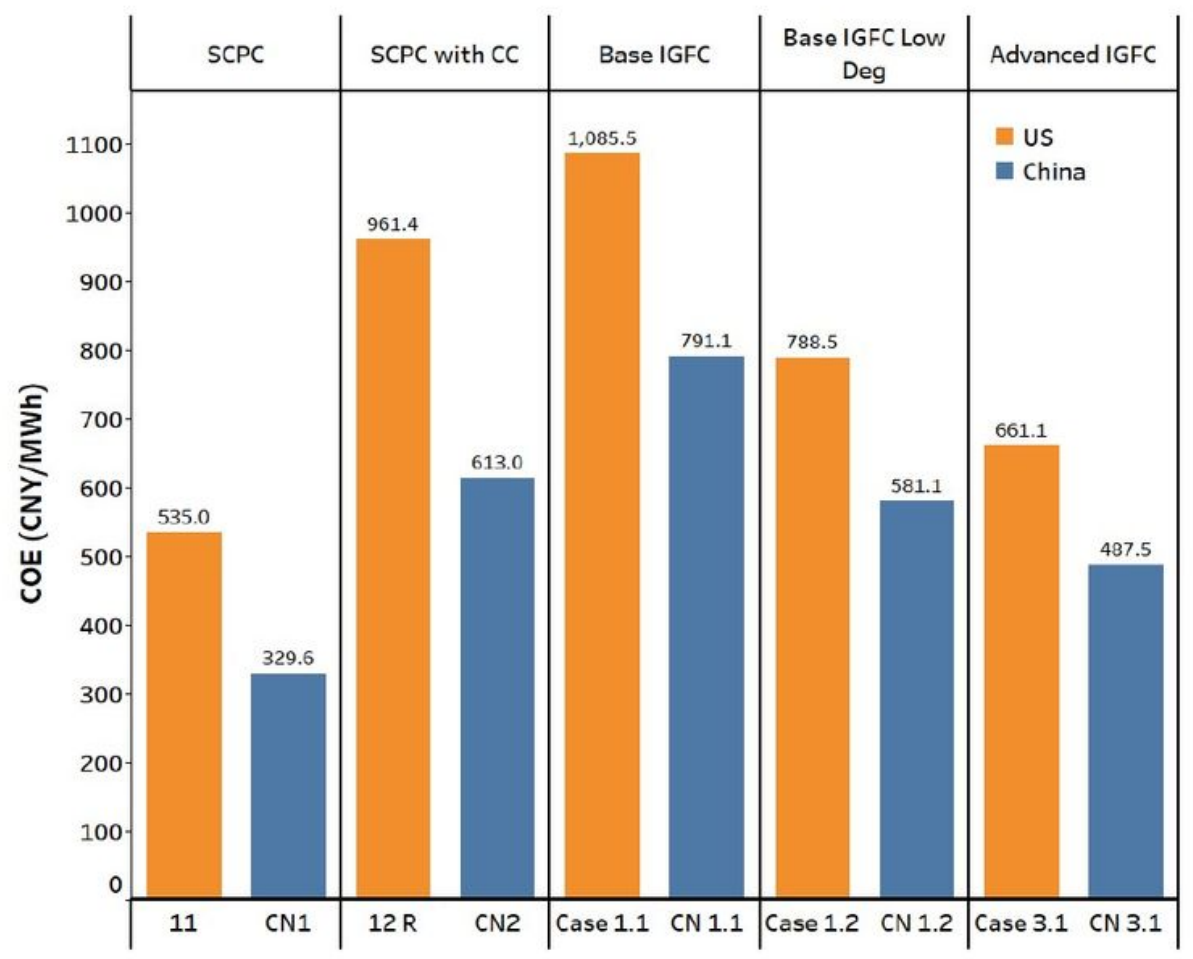

Figure 2: Cost of electricity (COE) of various IGFC systems cases as compared to SCPC without and with $\mathrm{CO} 2$ capture for US and China.

\section{Figure 2}

Cost of electricity (COE) of various IGFC systems cases as compared to SCP C without and with CO2 capture for US and China. 


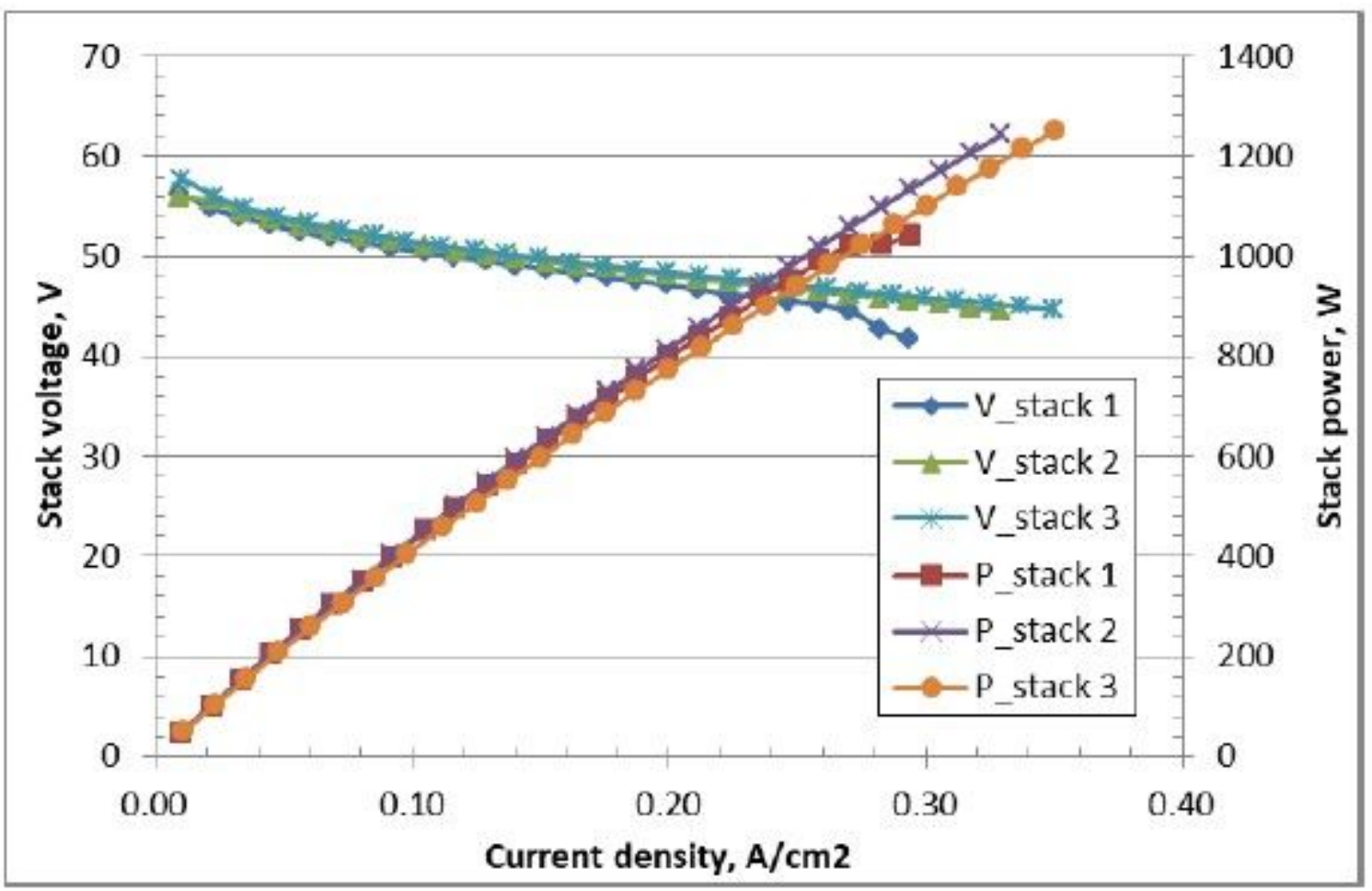

Figure $3 \mathrm{~V}$-I curves of SOFC stack (fuel flow rate is 9.0S LPM for stack 1, 12.0 SLPM for stack 2, and 13 SLPM for stack 3)

Figure 3

V I curves of SOFC stack (fuel flow rate is 9.0S L P M for stack 1, 12.0 SL P M for stack 2, and 13 SL P M for stack 3 


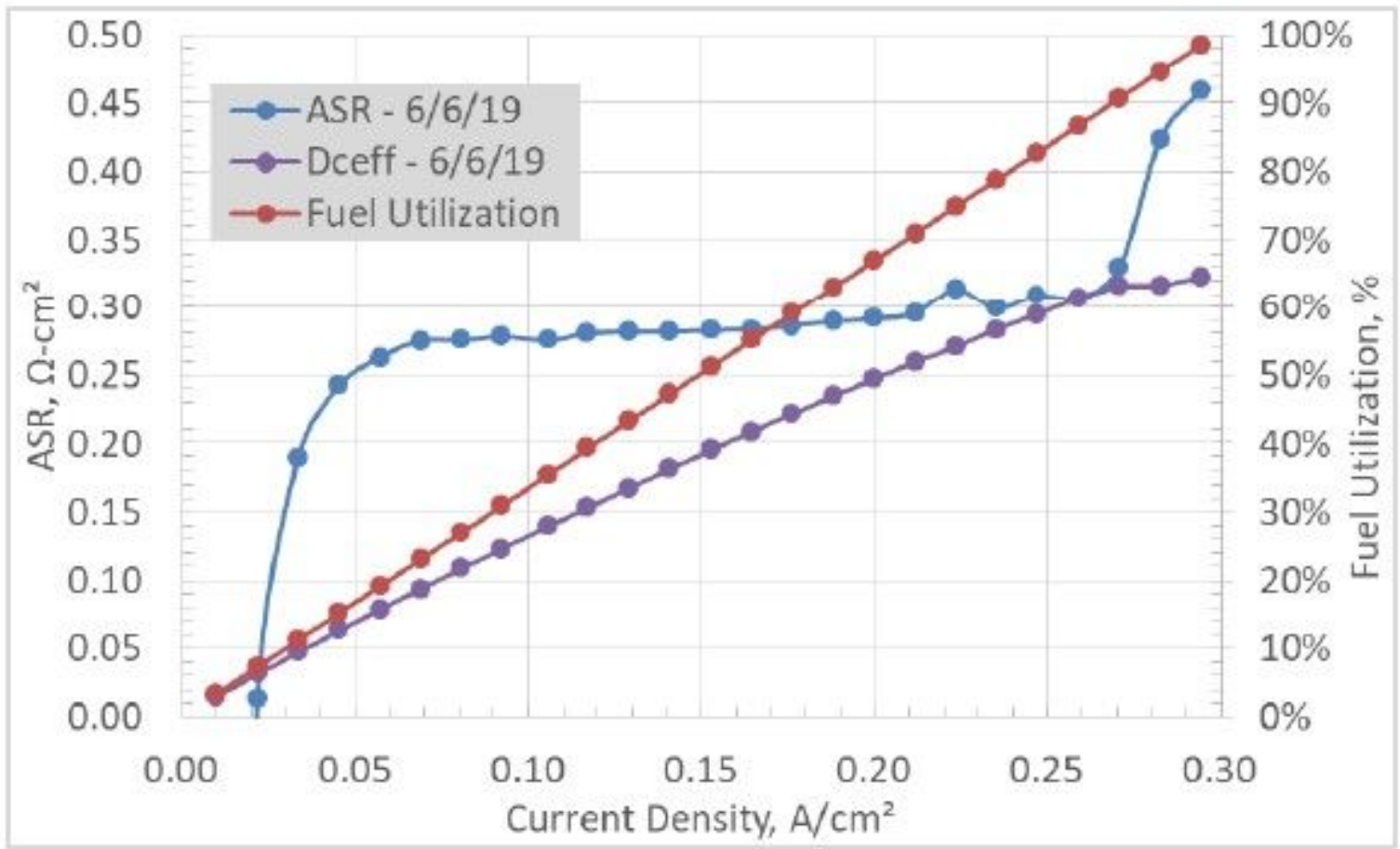

Figure 4 SOFC stack average ASR, DC power efficiency and fuel utilization vs. current density

Figure 4

SOFC stack average ASR, DC power efficiency and fuel utilization vs. current density 


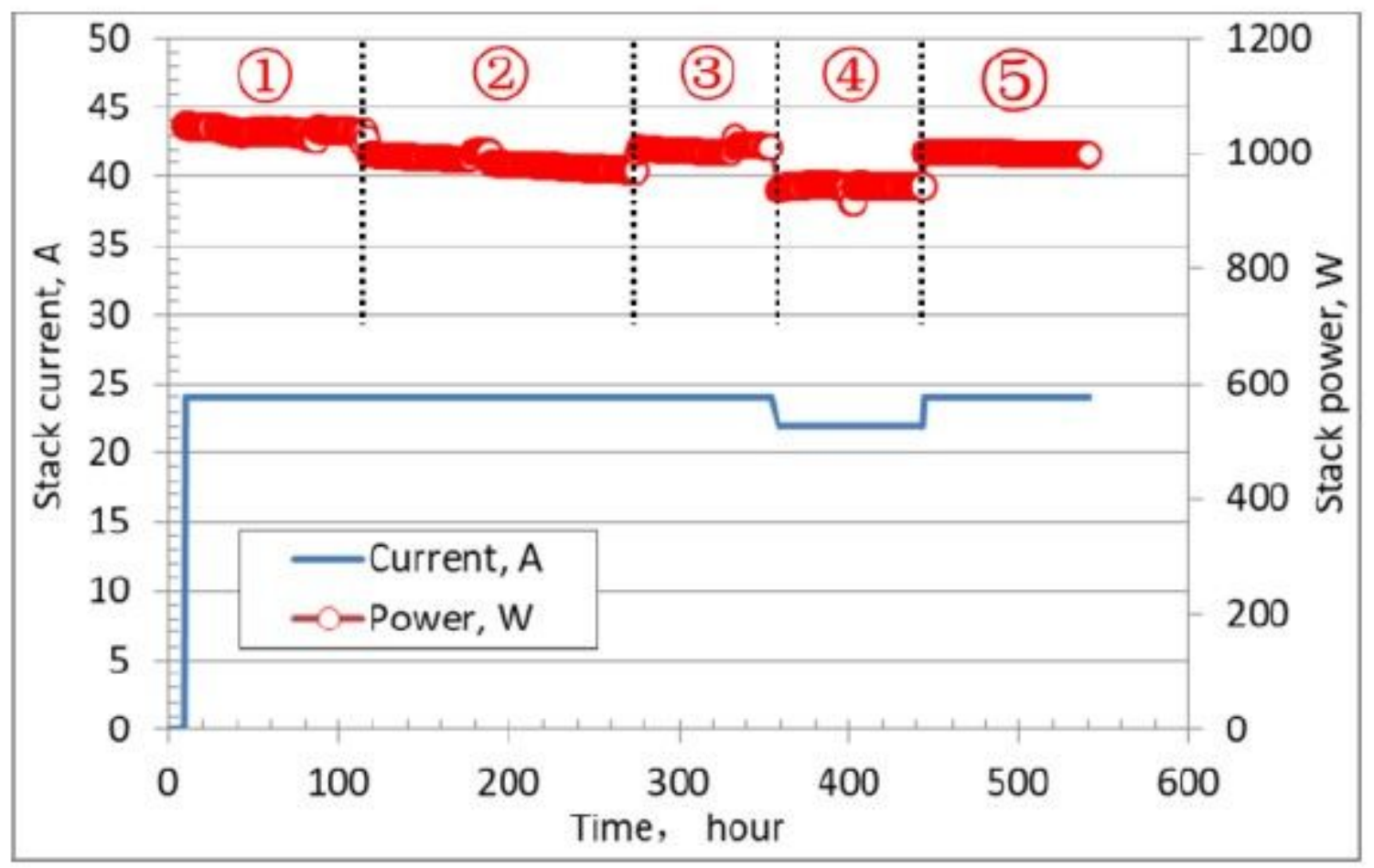

Figure 5 SOFC stack short term durability at $750^{\circ} \mathrm{C}$

Figure 5

SOFC stack short term durability at $750 \mathrm{oC}$ 
$\mathrm{H} 2 / \mathrm{CO}$ ratio $1.68: 1$

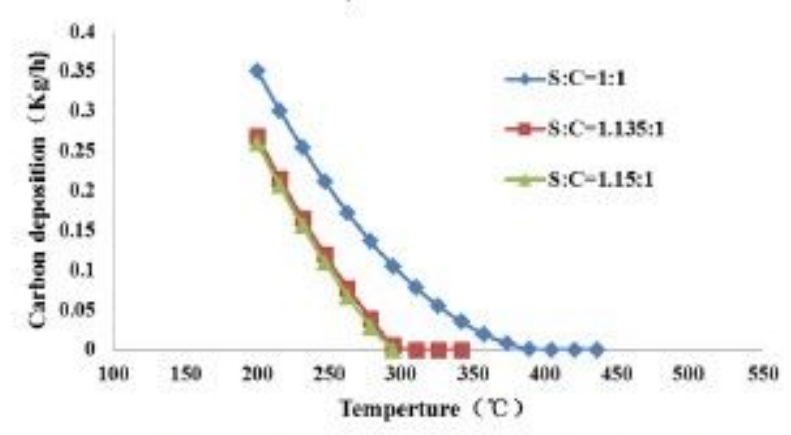

(a) $\mathrm{H} 2 / \mathrm{CO}=1.68: 1(61.8 \% \mathrm{H}, 37.7 \% \mathrm{CO})$

2

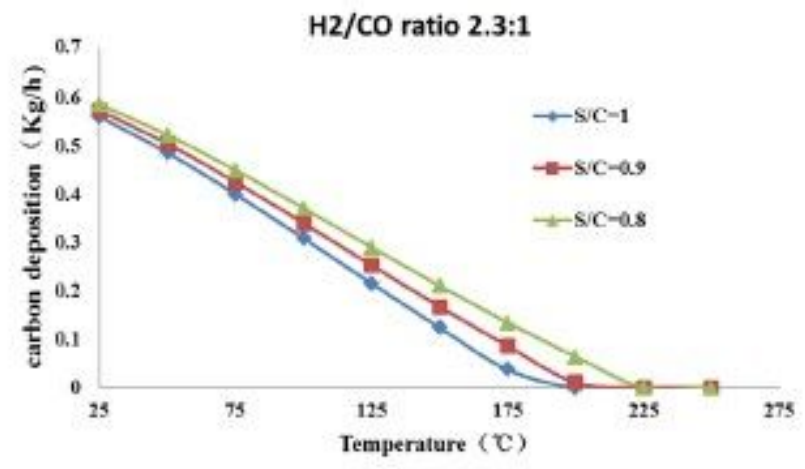

(b) $\mathrm{H} 2 / \mathrm{CO}=2.3: 1\left(69.7 \% \mathrm{H}_{2}, 30.3 \% \mathrm{CO}\right)$

$\mathrm{H} 2 / \mathrm{CO}$ ratio 2.9:1

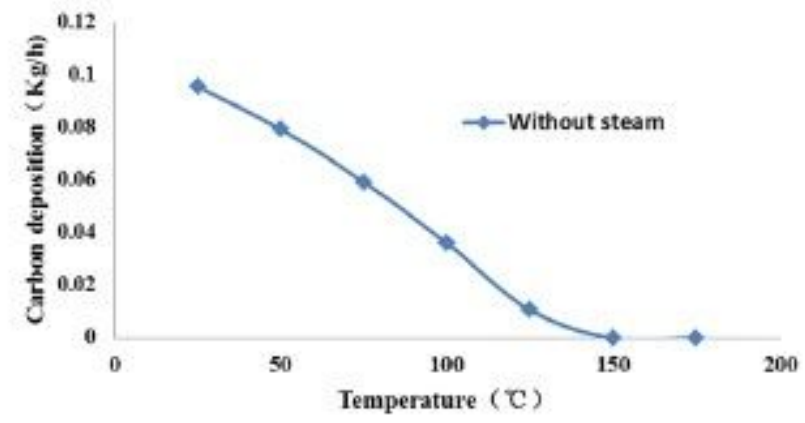

(c) $\mathrm{H} 2 / \mathrm{CO}=2.9: 1(74.4 \% \mathrm{H}, 25.6 \% \mathrm{CO})$

Figure 6 Potential carbon deposition analysis within fuel pipe for coal syngas with different $\mathrm{H} / \mathrm{CO}$ ratio using ASPEN Plus

2

Figure 6

Potential carbon deposition analysis within fuel pipe for coal syngas with different $\mathrm{H} 2 / \mathrm{CO}$ ratio using ASPEN Plus 


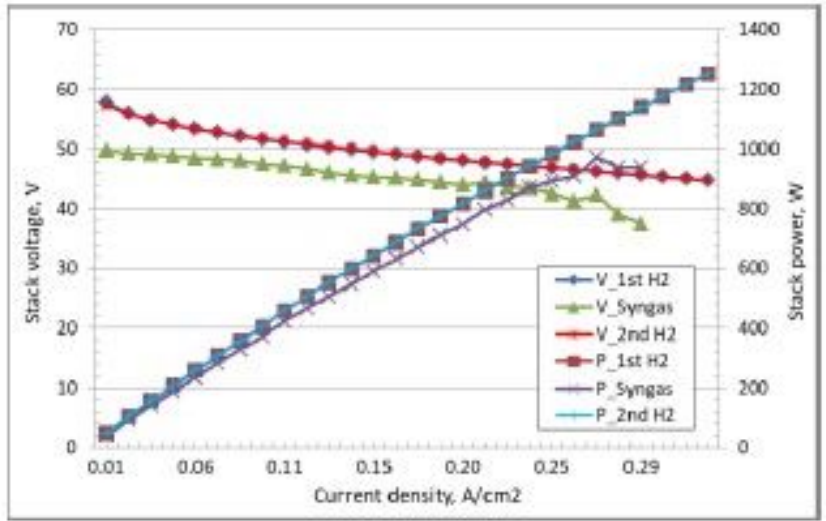

Figure 7 SOFC stack performance under $\mathrm{H} 2$ (flow rate: $13 \mathrm{SLM})$ and simulated coal syngas $\left(61.8 \% \mathrm{H}_{2}\right.$, $37.7 \% \mathrm{CO}$, flow rate: $13 \mathrm{SLM}$ with steam/CO ratio of 1.1)

\section{Figure 7}

SOFC stack performance under $\mathrm{H} 2$ (flow rate: $13 \mathrm{SLM})$ and simulated coal syngas $(61.8 \% \mathrm{H} 2,37.7 \% \mathrm{CO}$, flow rate:13 SLM with steam/CO ratio of 1.1)

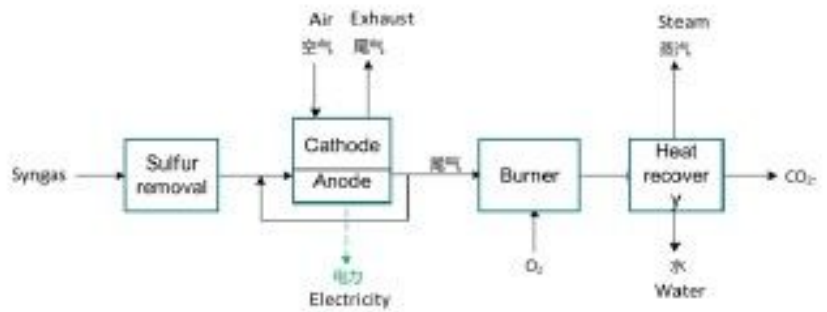

Figure 8 IGFC system flow chart using pipeline coal syngas

\section{Figure 8}

IGFC system flow chart using pipeline coal syngas 


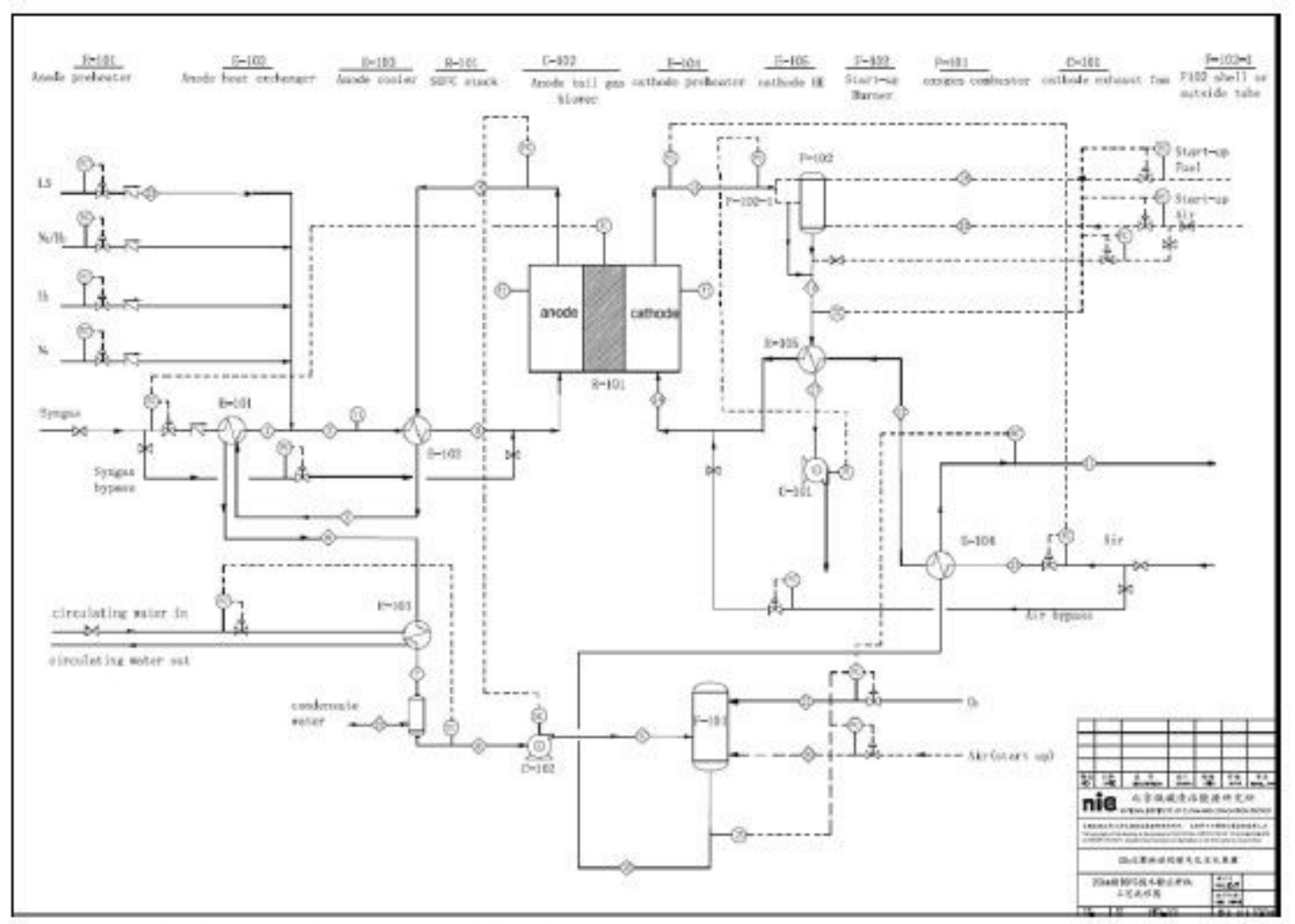

Figure 9 Process flow chart of the 20kW SOFC system

Figure 9

Process flow chart of the 20kW SOFC system 


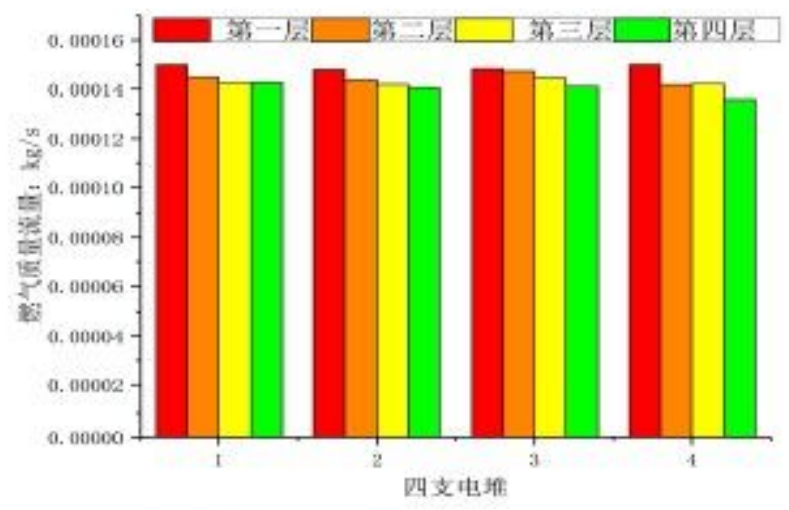

(a) Fuel flow distribution in SOFC stacks within $20 \mathrm{~kW}$ module

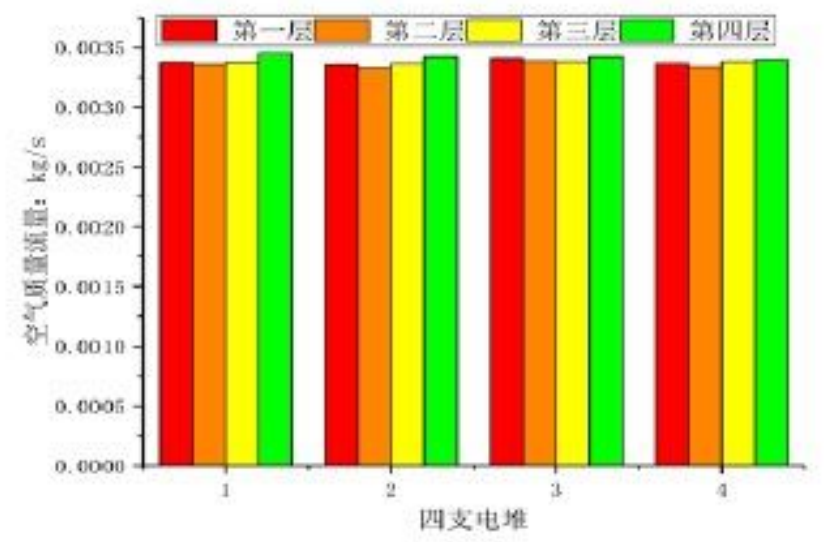

(b) Air flow distribution in SOFC stacks of $20 \mathrm{~kW}$ module

Figure 10 Gas flow distribution in SOFC stacks of $20 \mathrm{~kW}$ module

gas can be used to heat up cold air when the system starts at room temperatures. During system steady operation, the inlet air is heated up through a heat

Figure 10

Gas flow distribution in SOFC stacks of $20 \mathrm{~kW}$ module 


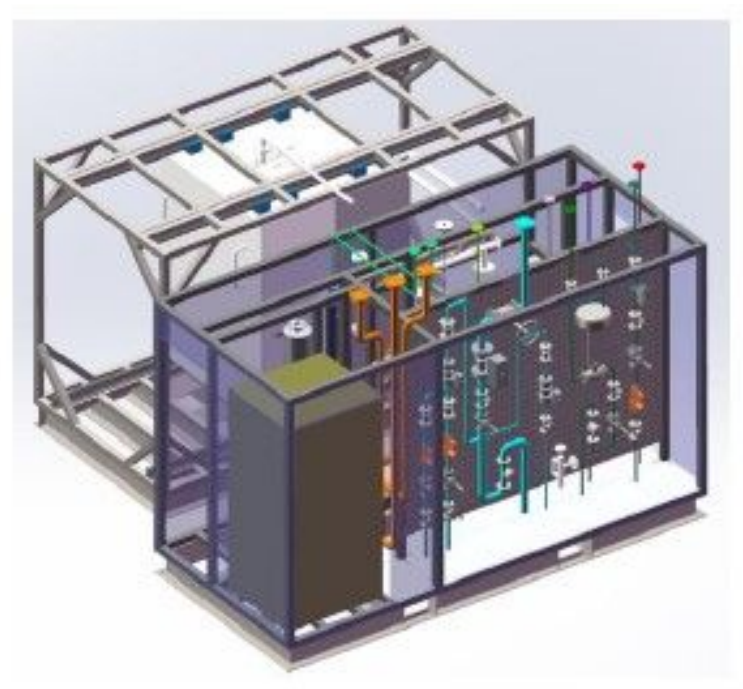

Figure $1120 \mathrm{~kW}$ SOFC power generation system being developed and constructed

\section{Figure 11}

20kW SOFC power generation s ystem being developed and constructed

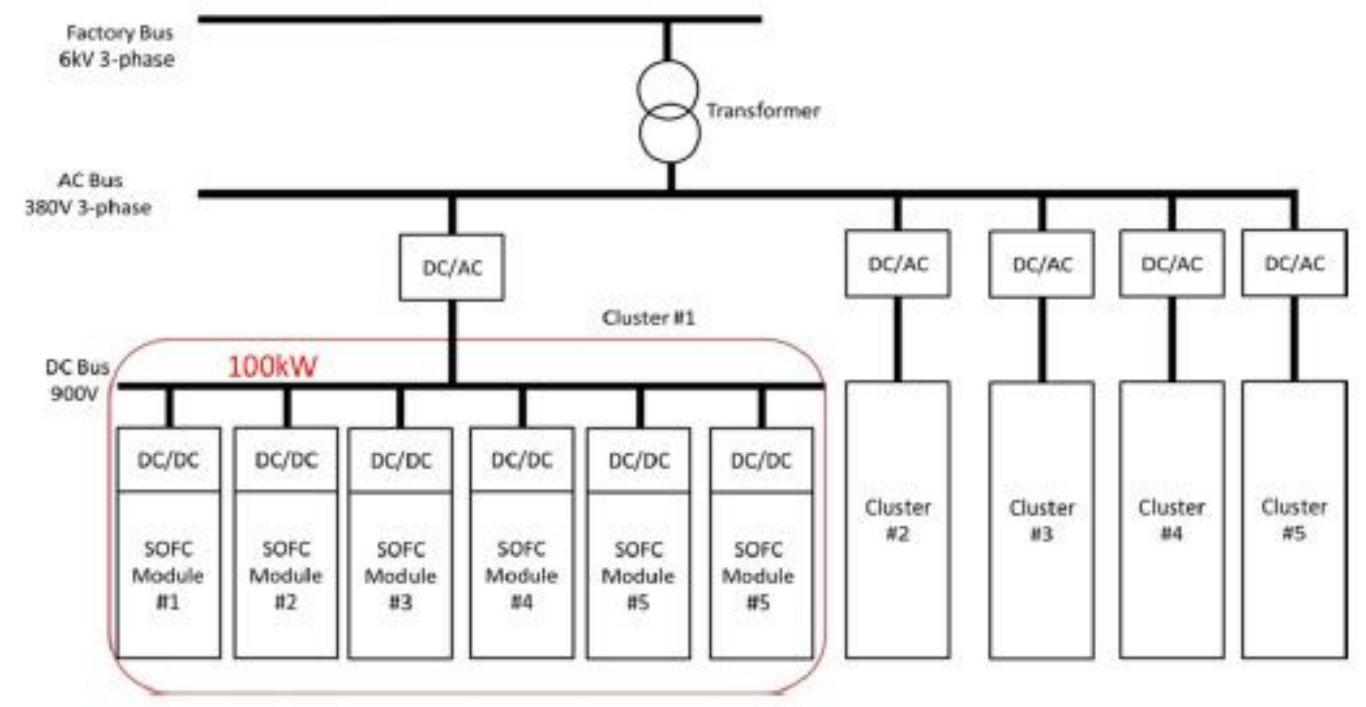

Figure $12500 \mathrm{~kW}$ SOFC power generation system conceptual design which consists of $5 \times 100 \mathrm{~kW}$ subsystem, and each subsystem consists of 5-6 SOFC modules which are electrically connected in parallel.

\section{Figure 12}

$500 \mathrm{~kW}$ SOFC power generation system conceptual design which consists of $5 \times 100 \mathrm{~kW}$ subsystem, and each subsystem consists of 5-6 SOFC modules which are electrically connected in parallel. 


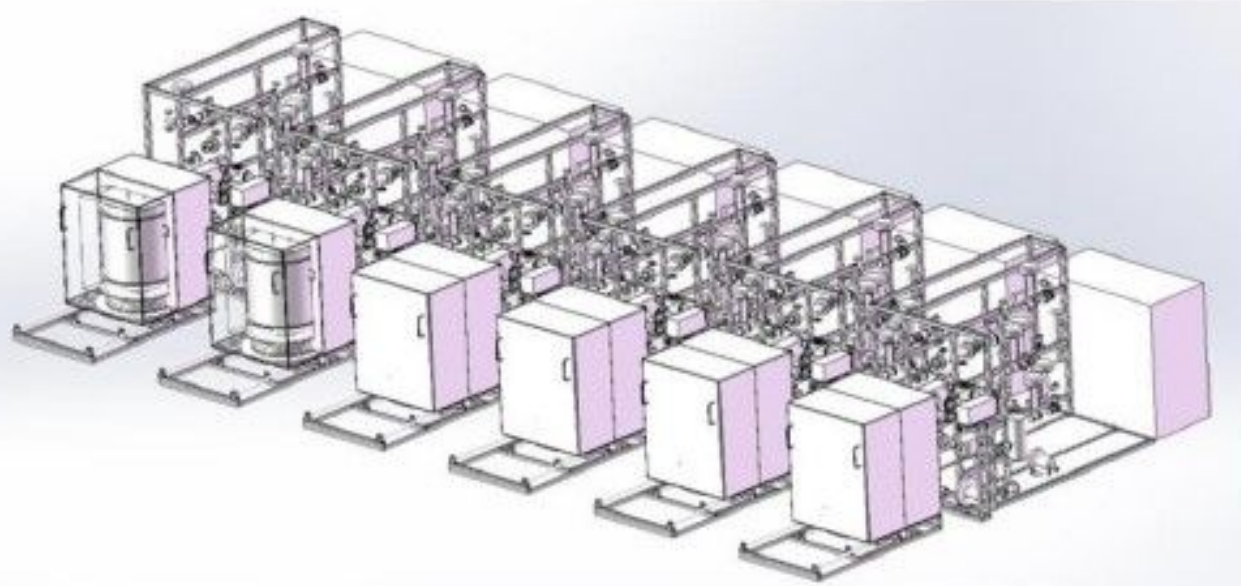

Figure $13100 \mathrm{~kW}$ SOFC power generation system conceptual design (consisting of $6 \times 20 \mathrm{~kW}$ modules for steady state operation)

\section{Figure 13}

100kW SOFC power generation system conceptual design (consisting of $6 \times 20 \mathrm{~kW}$ modules for steady state operation)

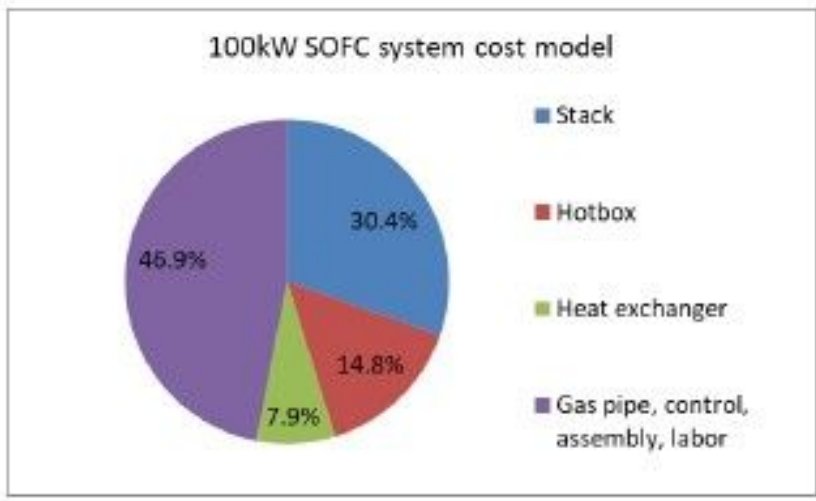

Figure 14 Cost model of 100kW SOFC system

\section{Figure 14}

Cost model of 100kW SOFC system 